bioRxiv preprint doi: https://doi.org/10.1101/734525; this version posted August 15,2019 . The copyright holder for this preprint (which was not certified by peer review) is the author/funder, who has granted bioRxiv a license to display the preprint in perpetuity. It is made available under aCC-BY-ND 4.0 International license.

1

2

3

4

5

6

FRAWLEY ET AL.: ETHNOBOTANICAL STUDY OF ELYMUS

8

9

Word count: 8080

10

11

12

13

14

15

16

17

18

19

20

21

22

23 


\section{An ethnobotanical study of the genus Elymus}

25 Emma S. Frawley ${ }^{1,3}$, Claudia Ciotir ${ }^{1,2}$, Brooke Micke ${ }^{1}$, Matthew J. Rubin ${ }^{3}$, and Allison J.

26 Miller ${ }^{1,2,3}$

27 ' 1 Saint Louis University, St. Louis, Missouri, USA.

$28 \quad{ }^{2}$ Missouri Botanical Garden, St. Louis, Missouri, USA.

$29{ }_{3}^{3}$ Donald Danforth Plant Science Center, St. Louis, Missouri, USA.

30 Abstract

Grains of domesticated grasses (Poaceae) have long been a global food source and

32 constitute the bulk of calories in the human diet. Recent efforts to establish more sustainable

33 agricultural systems have focused in part on the development of herbaceous, perennial crops.

34 Perennial plants have extensive root systems that stabilize soil and absorb water and nutrients at

35 greater rates than their annual counterparts; consequently, perennial grasses are important

36 potential candidates for grain domestication. While most contemporary grass domesticates

37 consumed by humans are annual plants, there are over 7,000 perennial grass species that remain

38 largely unexplored for domestication purposes. Documenting ethnobotanical uses of wild

39 perennial grasses could aid in the evaluation of candidate species for de novo crop development.

40 The objectives of this study are 1) to provide an ethnobotanical survey of the grass genus

41 Elymus; and 2) to investigate floret size variation in species used by people. Elymus includes

42 approximately 150 perennial species distributed in temperate and subtropical regions, of which at

43 least 21 taxa have recorded nutritional, medicinal, and/or material uses. Elymus species used for

44 food by humans warrant pre-breeding and future analyses to assess potential utility in perennial

45 agricultural systems.

$46 \quad$ Key Words 
47 Elymus, ethnobotany, fruit morphology, perennial agriculture, domestication, Poaceae.

Introduction

It is estimated that between $20 \%$ to $50 \%$ of the nearly 400,000 extant plant species in the

world may be edible to humans (Füleky 2009; Warren 2015); however, only 6,000 of these have

been cultivated for human consumption (FAO 2019). Cereals, members of the grass family

(Poaceae), include several widely cultivated species, such as barley (Hordeum vulgare L.), maize

(Zea mays L.), oats (Avena sativa L.), rice (Oryza sativa L.), rye (Secale cereale L.), sorghum

55 (Sorghum bicolor L. Moench), sugarcane (Saccharum officinarum L.), and wheat (Triticum modern agriculture (e.g., Khoury et al. 2014).

Cereal domestication began at least 12,000 years ago and resulted in morphological and genetic changes in cultivated plants relative to their wild progenitors (Glémin and Bataillon 2009; Olsen 2013a; Olsen 2013b). For example, domesticated grass species exhibit a reduction

64 in axillary branching, synchronization of maturation, and easy threshing (Zohary et al. 2012).

65 Further, domesticated grasses have larger seeds that require reduced stratification and display

66 decreased dormancy, shattering, and reduced or absent awns (Glémin and Bataillon 2009, Harlan

67 et al. 1973; Harlan 1992). These characteristics contribute to more uniform harvest time, plants

68 that can be grown in denser stands, increased seedling vigor, and more efficient harvesting

69 (Glémin and Bataillon 2009). Subsequent crop improvement programs have focused largely on 
70 enhanced grain production and nutritional qualities of domesticated grasses, resulting in

71 important alterations to a variety of seed traits, among other characteristics.

Grass species involved in early domestication processes were almost exclusively annuals

73 (NGS 2008), perhaps due to their high seed output (Cox 2009), adaptation to early agricultural

74 lands (DeHaan and Van Tassel 2014), and/or response to early selection efforts targeting

75 synchronized maturation (Glémin and Bataillon 2009). However, ecological impacts of

76 agricultural systems based on annual plants, including ongoing soil erosion and soil degradation

77 (e.g. Montgomery 2007) have turned attention to the potential role of herbaceous, perennial

78 species in contemporary agricultural systems. Perennials have deep root systems and longer

79 growing seasons resulting in reduced erosion risk and greater plant productivity over time

80 (Glover et al. 2010). Additionally, perennial species may be better adapted to temperature

81 increases driven by climate change, as they are less affected by changes in the uppermost soil

82 layer (Cox et al. 2006). As such, perennial crops may have an important role to play in the

83 development of more sustainable agricultural systems (Bommarco et al. 2013; Cassman 1999;

84 Ciotir et al. 2016; Ciotir et al. 2019; Cox et al. 2002; Doré et al. 2011; FAO 2009; Glover et al.

85 2010; Tittonell 2014).

Despite their potential utility, very few perennial grasses have been domesticated (Van

87 Tassel et al. 2010). Several hypotheses have been proposed to explain the near absence of

88 perennial, herbaceous crops. For example, some have suggested that their conservative resource

89 allocation to reproductive structures relative to vegetative structures hinders response to selection

90 for increased seed; others have proposed that herbaceous perennial plants exhibit reduced

91 competitive ability in agricultural habitats compared to annual species (DeHaan et al. 2010;

92 DeHaan and Van Tassel 2014). However, expanding understanding of agro-ecology, combined 
93 with new tools and analytical approaches, is driving increasing interest in pre-breeding of wild,

94 herbaceous, perennial species. Several herbaceous, perennial species are currently under

95 development, including perennial rice, sorghum, and wheat, among others (e.g., Cox et al. 2018;

96 DeHaan et al. 2016; Huang et al. 2018).

There are two primary ways in which perennial grass crops can be developed (DeHaan and Van Tassel, 2014). First, annual crops can be hybridized with their perennial wild relatives. This serves to introgress annual traits (like high yield, abiotic stress tolerance) into a perennial background (e.g. perennial wheat (Triticum aestivum x Thinopyrum intermedium) (DeHaan et al. 2018; Hayes et al. 2018) or vice versa. A second means of developing perennial grass crops is through de novo domestication of wild species, as is underway, for example, with the wild wheat relative Kernza (T. intermedium (Host) Barkworth \& D.R. Dewey) at the Land Institute (Salina,

$104 \mathrm{KS})$. However, one of the current challenges for de novo domestication is the identification of wild species for inclusion in pre-breeding programs (Ciotir et al. 2019). systems it is valuable to consider historical and contemporary ethnobotanical uses, as well as their fundamental morphological features and geographic distributions. Ethnobotanical and other data on plant diversity and use, including records of plant form preserved in herbarium specimens, are often housed in botanical gardens and museums (Miller et al. 2015). These

111 records offer a unique opportunity to explore agriculturally relevant questions about potential

112 candidates for domestication. For example, within a particular genus of grasses, how many 113 species are perennial? How many species have been used by people, what parts of the plant have 114 been used, and for what purposes? 
its compact and determinate inflorescence structure, capacity to self-pollinate, and current use as

117 forage, among other characteristics. Several Elymus species have been developed as forage

118 cultivars (e.g. blue wildrye (E. glaucus Buckley), thickspike wheatgrass (E. lanceolatus Scrib. \&

119 J.G. S.M), Canada wild rye (E. canadensis L.), slender wheatgrass (E. trachycaulus Link), Snake

120 River wheatgrass (E. wawawaiensis J. Carlson \& Buckley) and Virginia wildrye (E. virginicus

121 L.) (Aubry et al. 2005; Lloyd-Reilley 2010; Tilley et al. 2011). To date, multiple Elymus species

122 have been hybridized in a variety of pre-breeding initiatives. For example, there are at least

123 seventeen Elymus-wheat hybrids (Cox et al. 2002) that have been developed for drought and salt

124 tolerance (i.e. Elymus mollis Trin. x Triticum durum Desf.; Fatih 1983) and scab resistance (i.e.

125 E. trachycaulus x T. aestivum L., E. tsukushiensis Honda x T. aestivum; Kole 2011; Wang et al.

126 1999). Other Elymus hybrids include Elymus hoffmannii R.B. Jensen \& R.H. Assay, an advanced

127 generation hybrid between quackgrass (E. repens L.) and bluebunch wheatgrass

128 (Pseudoroegneria spicata (Pursh) Á. Löve) with drought and salinity tolerance (St. John 2010).

129 This work indicates Elymus is amenable to breeding processes and that some species within the

130 genus may hold promise for perennial grain crop development.

In this study we investigate Elymus to provide information that might facilitate evaluation

132 of species for use in de novo domestication processes. The specific objectives of this study were

133 to: 1) conduct an ethnobotanical survey of the genus Elymus; and 2) investigate floret size in

134 species used by people. These data provide valuable information about Elymus use and floret

135 size variation, and underscore how ethnobotanical studies can aid agricultural processes through

136 the evaluation of wild species and their potential applications in pre-breeding processes. 


\section{Study System}

Elymus includes approximately 150 wild, herbaceous, perennial species distributed across

141 North Temperate regions (Barkworth 2007; Lu 1993), including 39 species that occur in North

142 America (32 of which are native; Barkworth 2007). Elymus caryopses (grains) are typically

143 oblong to oblong-linear and adherent to the lemma and palea with hairy apices (Barkworth 2007;

144 Chen and Zhu 2006; Lu 1993). Inflorescences are erect spikes with one to three spikelets at each 145 node. Spikelets are ordinarily sessile with one to 11 florets. The lower florets are typically

146 functional, and the distal florets are often reduced (Barkworth 2007; Chen and Zhu 2006;

147 Kellogg 2015). Species that occur in western and northern North America have solitary spikelets, 148 whereas those found east of the Rocky Mountains have multiple spikelets per node (Barkworth 149 2007).

\section{Inclusion of Leymus}

Since the initial description of Elymus by Linnaeus, its taxonomy has varied under different taxonomic treatments (Helfgott and Mason-Gamer 2004; Lu 1993). Of particular

154 interest to this study is the genus Leymus Hochst., whose species have often been included in 155 circumscriptions of Elymus. Three Leymus species presented in this survey, L. cinereus (Scribn.

156 \& Merr.) Á. Löve, L. condensatus (J. Presl) Á. Löve, and L. triticoides (Buckley) Pilg., were 157 originally described as Elymus species by previous authors (E. cinereus Scribin. \& Merr., $L$. 158 condensatus J. Presl, and E. triticoides Buckley), but are now considered synonyms for Leymus. 159 We included these species in our results because some ethnobotanical descriptions surveyed here treat them as Elymus, and all three were used extensively by indigenous communities in the 161 American southwest. 


\section{Ethnobotanical analysis of Elymus}

We performed a literature review to investigate recorded uses of Elymus species. We surveyed 121 print resources accessed at the Peter H. Raven Library at the Missouri Botanical Elymus is known to occur; 2) ethnobotanical studies focused specifically on cultures of native communities located in these regions; and 3) global assessments of edible plants. We surveyed two online ethnobotany databases, Native American Ethnobotany Database (http://naeb.brit.org/) and Plants for a Future (https://pfaf.org/), and two online scientific databases, JSTOR

171 (http://www.jstor.org) and Web of Science (http://www.webofknowledge.com/WOS) for relevant

172 information about Elymus. We collected data on historical use by indigenous communities,

173 human and animal edibility, cultivation history, and the uses of different plant parts. Results

174 were recorded in the Perennial Agriculture Project Global Inventory online database

175 (http://www.tropicos.org/Project/PAPGI). We also collected data on geographic distributions

176 from specimen data at the Missouri Botanical Garden herbarium and from the Global

177 Biodiversity Information Facility (www.gbif.org). Ethnobotanical uses were categorized as food,

178 forage, medicine, and/or material. The food category included species that were consumed by

179 humans; the forage category identified species cultivated for growth in pastures and for

180 consumption by livestock; the medicine category designated species that were used in

181 ceremonial decoctions or had therapeutic or healing utilities; finally, the material group covered

182 species used as tools, housewares, and in construction, as well as other applications as raw 183 materials. 


\section{Measurements of floret traits from herbarium specimens}

Grain morphology is an important target of selection in grass species undergoing

187 domestication for human consumption (Glemín and Batallion 2009). While many wild species

188 have relatively small, long, thin grains, selection during domestication generally favors larger,

189 rounder grains (Gegas 2010; Okamoto 2012; Stougaard and Xue, 2004). We were interested in

190 surveying grain size variation in species with documented ethnobotanical uses. We hypothesized

191 that Elymus species used for human consumption may display larger grain sizes than those used

192 for other purposes. A definition of the "pure seed unit" for crop conditioning is the floret: the

193 reproductive structure including the lemma, palea, and caryopsis (grain), and excluding the awn

194 when the awn length is longer than that of the entire floret (Gregg and Billups 2010). There is a

195 positive correlation between floret cavity size (volume) and grain growth, including grain size

196 and weight (Millet and Pinthus 1984; Millet 1986).

We calculated floret area for Elymus species with documented histories of use to examine relationships between floret size, ethnobotanical use, and collection location. Our ethnobotanical analysis identified 21 species with ethnobotanical uses (see results below). For each of these 21

200 species, we selected Elymus specimens from the herbarium at the Missouri Botanical Garden 201 based on their collection location, targeting specimens that had been collected in a country or 202 state where Elymus use by indigenous communities had been documented (Figure 1). If there 203 was no indigenous community specifically identified for a taxon, we selected a specimen from

204 the species known native range. For example, because E. canadensis was used historically in 205 Utah and Colorado, sampled specimens came from these states (Table 1). 
bioRxiv preprint doi: https://doi.org/10.1101/734525; this version posted August 15, 2019. The copyright holder for this preprint (which was not certified by peer review) is the author/funder, who has granted bioRxiv a license to display the preprint in perpetuity. It is made available under aCC-BY-ND 4.0 International license.

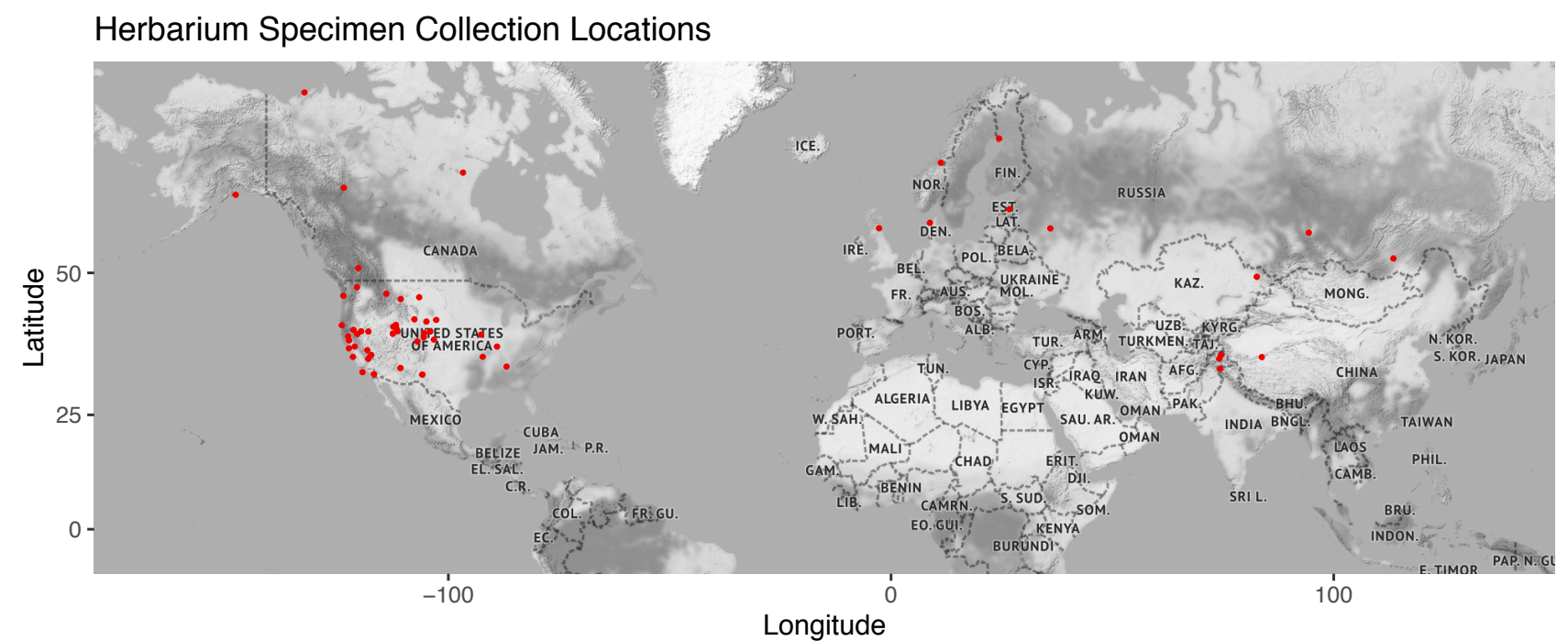

Figure 1. Geographic locations of collection sites for all specimens measured across 21 Elymus species. Collection site determined from herbarium specimen label.

\begin{tabular}{|c|c|c|}
\hline Species & Use Distribution & Native Range \\
\hline E. arenarius (L.) & Eurasia (NOR) & Eurasia \\
\hline E. canadensis (L.) & North America (UT, CO) & North America \\
\hline E. caninus (L.) & Eurasia (RUS, CHN) & Temperate Asia \\
\hline E. elongatus (Host.) & North America (USA, CAN) & Eurasia \\
\hline E. elymoides (Raf.) & North America (CA) & $\begin{array}{l}\text { North America, } \\
\text { Temperate Asia }\end{array}$ \\
\hline E. fibrosus (Schrenk) & Eurasia (RUS) & Temperate Asia \\
\hline E. glaucus (Buckley) & North America (CA, NM, BC) & $\begin{array}{l}\text { North America, } \\
\text { Temperate Asia }\end{array}$ \\
\hline E. hystrix (Moench) & North America (FL) & North America \\
\hline $\begin{array}{l}\text { E. lanceolatus (Scribn. \& } \\
\text { J.G. Sm.) }\end{array}$ & North America (USA, CAN) & $\begin{array}{l}\text { North America, } \\
\text { Temperate Asia }\end{array}$ \\
\hline E. mollis (Trin.) & North America (AK, BC, WA) & $\begin{array}{l}\text { North America, } \\
\text { Eurasia }\end{array}$ \\
\hline E. multisetus (J.G. Sm.) & North America (CA) & North America \\
\hline E. mutabilis (Drobow) & Eurasia (RUS) & Eurasia \\
\hline E. repens (L.) & $\begin{array}{l}\text { North America (USA, CAN); Eurasia (FIN, } \\
\text { SWE, RUS, TUR, BIH, IRL) }\end{array}$ & Eurasia \\
\hline $\begin{array}{l}\text { E. semicostatus (Nees ex } \\
\text { Steud.) }\end{array}$ & North America (USA); Eurasia (JPN) & Asia \\
\hline E. sibiricus (L.) & North America (UT); Eurasia (RUS) & $\begin{array}{l}\text { North America, } \\
\text { Eurasia }\end{array}$ \\
\hline E. smithii (Rydb.) & North America (USA, CAN) & North America \\
\hline E. spicatus (Pursh) & North America (USA) & North America \\
\hline E. trachycaulus (Link) & North America (USA, CAN); Eurasia (RUS) & $\begin{array}{l}\text { North America, } \\
\text { Eurasia }\end{array}$ \\
\hline $\begin{array}{l}\text { L. cinereus (Scribn. \& } \\
\text { Merr.) }\end{array}$ & North America (AB, BC, MT, UT, CA) & North America \\
\hline L. condensatus (J. Presl) & North America (UT, CA) & North America \\
\hline L. triticoides (Buckley) & North America (CA) & North America \\
\hline
\end{tabular}


Table 1. Native ranges and location of ethnobotanical use for 21 Elymus species.

213 we sampled three herbarium specimens per species and harvested eight florets from each

214 specimen, with the exception of E. semicostatus Nees ex Steud., for which only two herbarium

215 specimens existed. For every specimen, we recorded the location of collection, accession and

216 collection number, collection date, collector, and latitude and longitude when available

217 (Appendix 1). We removed the glumes to reveal the caryopsis enclosed by the adherent palea

218 and the lemma. We imaged florets in high resolution (iPhone XR, DPI 326) at the Missouri

219 Botanical Garden herbarium and measured area in ImageJ (v. 1.50i). We returned plant material

220 to the fragment packet on the herbarium sheet following imaging. We cropped each image to

221 encompass only the seeds, then converted the image to binary to analyze particles for individual

222 and average floret area $\left(\mathrm{mm}^{2}\right)$. Raw data for floret area is available in Appendix 2. We fit linear

223 models in R (v. 1.0.143, RStudio Team 2015) and SAS (v. 9.4, SAS Institute 2017) to investigate

224 three main questions: 1) does individual floret area differ between species and among replicates

225 within a species, 2) do average floret areas vary with ethnobotanical uses in a given region, and

2263 ) is there an association between average floret area and latitude and longitude? While Elymus

227 hystrix Moench was described in the literature as being used medicinally, its specific application

228 (maize seed germination: Table 2) was not consistent with the other species' medicinal uses.

229 Therefore we removed E. hystrix when testing for an effect of medicinal usage on floret size. 
bioRxiv preprint doi: https://doi.org/10.1101/734525; this version posted August 15,2019 . The copyright holder for this preprint (which was not certified by peer review) is the author/funder, who has granted bioRxiv a license to display the preprint in perpetuity. It is made available under aCC-BY-ND 4.0 International license.

\begin{tabular}{|c|c|c|c|c|c|c|c|}
\hline Species & $\begin{array}{l}\text { Indigenous } \\
\text { Communities }\end{array}$ & $\begin{array}{l}\text { Plant Part } \\
\text { Used }\end{array}$ & Food Uses & Medicinal Uses & Forage Uses & Material Uses & References \\
\hline $\begin{array}{l}\text { E. arenarius } \\
\text { (L.) }\end{array}$ & Unspecified & Unspecified & Unspecified & Unspecified & Unspecified & $\begin{array}{l}\text { Twisting ropes and } \\
\text { making brooms. }\end{array}$ & $\begin{array}{l}\text { Hooker 1839; } \\
\text { Moerman 1998. }\end{array}$ \\
\hline $\begin{array}{l}\text { E. canadensis } \\
\text { (L.) }\end{array}$ & $\begin{array}{l}\text { Gosiute (G), } \\
\text { Iroquois (I), Kiowa } \\
\text { (K), Ute (U), Paiute } \\
\text { (P) }\end{array}$ & $\begin{array}{l}\text { Seeds, roots, } \\
\text { and foliage }\end{array}$ & $\begin{array}{l}\text { Gathered }(\mathbf{G}, \mathbf{U}) \text {, ground } \\
\text { into flour, used to make } \\
\text { bread, cereals, rye } \\
\text { casserole. }\end{array}$ & $\begin{array}{l}\text { Compound decoction of roots taken } \\
\text { for the kidneys (I). }\end{array}$ & $\begin{array}{l}\text { Fodder }(\mathbf{K}) \text {; forage } \\
\text { for deer, antelope, } \\
\text { and buffalo }(\mathbf{P}) ; \\
\text { cultivated as a } \\
\text { pasture grass }(\mathbf{P}) \text {. }\end{array}$ & Unspecified & $\begin{array}{l}\text { Facciola 1990; } \\
\text { Kindscher 1987; } \\
\text { Kunkel 1984; } \\
\text { Moerman 1998; } \\
\text { Tanaka 1976; } \\
\text { Yanovsky 1936. }\end{array}$ \\
\hline $\begin{array}{l}\text { E. caninus } \\
\text { (L.) }\end{array}$ & Unspecified & Unspecified & Unspecified & Unspecified & Forage grass. & Unspecified & Hanelt 2001. \\
\hline $\begin{array}{l}\text { E. elongatus } \\
\text { (Host.) }\end{array}$ & Unspecified & Unspecified & Unspecified & Unspecified & $\begin{array}{l}\text { Hay and pasture } \\
\text { crop. }\end{array}$ & Unspecified & Hanelt 2001. \\
\hline $\begin{array}{l}\text { E. elymoides } \\
\text { (Raf.) }\end{array}$ & $\begin{array}{l}\text { Navajo (N), Ramah } \\
\text { (R), Potter Valley } \\
\text { Pomo (PVP) }\end{array}$ & Seeds & $\begin{array}{l}\text { As pinole, considered } \\
\text { second best quality after } \\
\text { wild oats (PVP). }\end{array}$ & Unspecified & $\begin{array}{l}\text { Young plants used } \\
\text { for sheep and } \\
\text { horse feed }(\mathbf{N}, \mathbf{R}) \text {. }\end{array}$ & Unspecified & $\begin{array}{l}\text { Moerman 1998; } \\
\text { Welch 2013. }\end{array}$ \\
\hline $\begin{array}{l}\text { E. fibrosus } \\
\text { (Schrenk) }\end{array}$ & Unspecified & Unspecified & Unspecified & Unspecified & Minor forage crop. & Unspecified & $\begin{array}{l}\text { Clayton et al. 2006; } \\
\text { Hanelt 2001. }\end{array}$ \\
\hline $\begin{array}{l}\text { E. glaucus } \\
\text { (Buckley) }\end{array}$ & $\begin{array}{l}\text { Karok (KA), Keres } \\
\text { (KE), Gitksan (GI) }\end{array}$ & Seeds & $\begin{array}{l}\text { As porridge (seeds } \\
\text { parched, pounded into a } \\
\text { flour, and mixed with } \\
\text { water into a paste), } \\
\text { cooked, or ground into } \\
\text { bread flour (KA). }\end{array}$ & $\begin{array}{l}\text { To settle quarrels between families } \\
\text { or individuals }(\mathbf{K A}) \text {. }\end{array}$ & $\begin{array}{l}\text { Forage for deer, } \\
\text { antelope, and } \\
\text { buffalo; potential } \\
\text { pasture and forage } \\
\text { crop. }\end{array}$ & $\begin{array}{l}\text { Used in socks and } \\
\text { stuffing inside } \\
\text { moccasins, as baby } \\
\text { bedding, and to cover } \\
\text { ground where people } \\
\text { sat around fire (GI). }\end{array}$ & $\begin{array}{l}\text { Couplan 1998; } \\
\text { Ebeling 1986; Hanelt } \\
\text { 2001; Moerman 1998; } \\
\text { Schenck 1952; Smith } \\
\text { 1997; Smith Jr. 2014; } \\
\text { Tanaka 1976; } \\
\text { Yanovsky 1936. }\end{array}$ \\
\hline $\begin{array}{l}\text { E. hystrix } \\
\text { (Moench) }\end{array}$ & Iroquois & Unspecified & Unspecified & $\begin{array}{l}\text { Ceremonial: decoction for corn } \\
\text { seeds (I). }\end{array}$ & Unspecified & Unspecified & Austin 2004. \\
\hline $\begin{array}{l}\text { E. lanceolatus } \\
\text { (Scribn. \& } \\
\text { J.G. Sm.) }\end{array}$ & Unspecified & Unspecified & Unspecified & Unspecified & $\begin{array}{l}\text { Cultivated as } \\
\text { forage grass and } \\
\text { pasture crop. }\end{array}$ & Unspecified & Hanelt 2001. \\
\hline $\begin{array}{l}\text { E. mollis } \\
\text { (Trin.) }\end{array}$ & $\begin{array}{l}\text { Nitinaht (NI), } \\
\text { Makah (M), Haida } \\
\text { (H), Nunivak } \\
\text { Eskimo (NE) }\end{array}$ & $\begin{array}{l}\text { Seeds, stems, } \\
\text { leaves, and } \\
\text { roots }\end{array}$ & Seeds eaten. & $\begin{array}{l}\text { Roots twisted together to form rope, } \\
\text { rubbed on the bodies of young men } \\
\text { for strength }(\mathbf{N I}) \text {; basal portion of } \\
\text { stem chewed for incontinence }(\mathbf{M}) \text {. }\end{array}$ & Unspecified & $\begin{array}{l}\text { Tough leaves used } \\
\text { for sewing ( } \mathbf{~ I I ) , ~} \\
\text { plants gathered, split, } \\
\text { dyed, and used in } \\
\text { basketry and mats } \\
(\mathbf{H} ; \mathbf{N E}) \text {. }\end{array}$ & $\begin{array}{l}\text { Couplan 1998; Turner } \\
\text { et al. 1983; Turner } \\
\text { 2010; Lantis 1946. }\end{array}$ \\
\hline $\begin{array}{l}\text { E. multisetus } \\
\text { (J.G. Sm.) }\end{array}$ & Kawaiisu (KW) & Seeds & $\begin{array}{l}\text { Pounded into a } \\
\text { porridge/mush }(\mathbf{K W}) \text {. }\end{array}$ & Unspecified & Unspecified & Unspecified & $\begin{array}{l}\text { Moerman 1998; Smith } \\
\text { Jr. } 2014 \text {. }\end{array}$ \\
\hline $\begin{array}{l}\text { E. mutabilis } \\
\text { (Drobow) }\end{array}$ & Unspecified & Unspecified & Unspecified & Unspecified & $\begin{array}{l}\text { Frost-resistent } \\
\text { forage grass. }\end{array}$ & Unspecified & Hanelt 2001. \\
\hline E. repens (L.) & $\begin{array}{l}\text { Apache (A), White } \\
\text { Mountain (WM), } \\
\text { Cherokee (CHE), } \\
\text { Gosiute, Iroquois, } \\
\text { Okanagan-Colville } \\
\text { (OC), Lukomir } \\
\text { Highlanders (LH) }\end{array}$ & $\begin{array}{l}\text { Seeds, stems, } \\
\text { rhizomes, } \\
\text { roots, shoots, } \\
\text { and leaves }\end{array}$ & $\begin{array}{l}\text { Roots dried, ground into } \\
\text { meal, and substituted for } \\
\text { bread; rhizomes dried and } \\
\text { ground, roasted for coffee, } \\
\text { or boiled into a syrup for } \\
\text { beer; seeds, tips of } \\
\text { rhizomes, leaves and } \\
\text { shoots eaten raw; seed } \\
\text { mashed (A; WM; } \mathbf{G}) \text {. }\end{array}$ & $\begin{array}{l}\text { Orthopedic and unrinary aid (CHE; } \\
\text { I); decoction used to wash swollen } \\
\text { legs and infusion taken for gravel, } \\
\text { incontinence, and bedwetting } \\
\text { (CHE); roots infused to make } \\
\text { kidney and genitourinary treatment; } \\
\text { rhizomes to treat kidney, liver, and } \\
\text { urinary problems; worm expellant } \\
\text { (I); to treat poor eyesight, chest pain, } \\
\text { fever, syphilis, jaundice, and } \\
\text { swollen and rheumatic limbs; other } \\
\text { medicinal uses (LH). }\end{array}$ & $\begin{array}{l}\text { Fodder and forage } \\
\text { plant for hay (A; } \\
\text { WM), N. } \\
\text { American cultivar } \\
\text { 'Newhy' promising } \\
\text { forage hybrid ( } E \text {. } \\
\text { repens } \mathrm{x} E \text {. } \\
\text { spicatus). }\end{array}$ & $\begin{array}{l}\text { Used under and over } \\
\text { food in pit cooking } \\
\text { (OC). }\end{array}$ & $\begin{array}{l}\text { Allen and Hatfield } \\
\text { 2004; Elliot 2009; } \\
\text { Ferrier et al. 2015; } \\
\text { Hanelt 2001; Jackson } \\
\text { 2014; MacKinnon et } \\
\text { al. 2009; Moerman } \\
1998 \text {; Sargin } 2013 \text {. }\end{array}$ \\
\hline $\begin{array}{l}\text { E. } \\
\text { semicostatus } \\
\text { (Nees ex } \\
\text { Steud.) }\end{array}$ & Unspecified & Unspecified & Unspecified & Unspecified & $\begin{array}{l}\text { Drought-resistent } \\
\text { pasture grass. }\end{array}$ & Unspecified & $\begin{array}{l}\text { Clayton et al. 2006; } \\
\text { Hanelt 2001. }\end{array}$ \\
\hline $\begin{array}{l}\text { E. sibiricus } \\
\text { (L.) }\end{array}$ & $\begin{array}{l}\text { Gosiute } \\
\end{array}$ & Seeds & Yes $(\mathbf{G})$ & Unspecified & $\begin{array}{l}\text { Infrequently } \\
\text { cultivated as } \\
\text { forage grass. }\end{array}$ & Unspecified & $\begin{array}{l}\text { Chamberlin 1911; } \\
\text { Clayton et al. 2006; } \\
\text { Hanelt 2001; } \\
\text { Moerman 1998. }\end{array}$ \\
\hline $\begin{array}{l}\text { E. smithii } \\
\text { (Rydb.) }\end{array}$ & Unspecified & Unspecified & Unspecified & Unspecified & $\begin{array}{l}\text { Cultivated for hay } \\
\text { and pasture. }\end{array}$ & Unspecified & $\begin{array}{l}\text { Clayton et al. 2006; } \\
\text { Hanelt 2001. }\end{array}$ \\
\hline $\begin{array}{l}\text { E. spicatus } \\
\text { (Pursh) }\end{array}$ & Unspecified & Unspecified & Unspecified & Unspecified & $\begin{array}{l}\text { Forage grass for } \\
\text { natural pastures. }\end{array}$ & Unspecified & $\begin{array}{l}\text { Clayton et al. 2006; } \\
\text { Hanelt 2001. }\end{array}$ \\
\hline $\begin{array}{l}\text { E. } \\
\text { trachycaulus } \\
\text { (Link) }\end{array}$ & Unspecified & Seeds & Unspecified & Unspecified & $\begin{array}{l}\text { Cultivated mostly } \\
\text { in grass mixtures } \\
\text { as forage and } \\
\text { pasture plant. }\end{array}$ & Unspecified & $\begin{array}{l}\text { Clayton et al. 2006; } \\
\text { Hanelt 2001; Smith Jr. } \\
\text { 2014. }\end{array}$ \\
\hline $\begin{array}{l}\text { L. cinereus } \\
\text { (Scribn. \& } \\
\text { Merr.) Á. } \\
\text { Löve }\end{array}$ & $\begin{array}{l}\text { Paiute, Thompson } \\
\text { (T), Blackfoot (B) }\end{array}$ & $\begin{array}{l}\text { Seeds, stems, } \\
\text { leaves, and } \\
\text { culm }\end{array}$ & Seeds eaten $(\mathbf{P})$. & Unspecified & $\begin{array}{l}\text { Hay for livestock } \\
\text { (T). }\end{array}$ & $\begin{array}{l}\text { Stems used for } \\
\text { basket imbrication; } \\
\text { leaves used to line } \\
\text { graves; culms used as } \\
\text { "fish spreaders" or } \\
\text { for cleaning; grass } \\
\text { used as bedding }(\mathbf{T}) \text {. }\end{array}$ & $\begin{array}{l}\text { Ebeling 1986; } \\
\text { Johnston 1970; Turner } \\
\text { et al. 1996; Smith Jr. } \\
2014 .\end{array}$ \\
\hline $\begin{array}{l}L . \\
\text { condensatus } \\
\text { (J. Presl) Á. } \\
\text { Löve }\end{array}$ & $\begin{array}{l}\text { Cahuilla (C), } \\
\text { Gosiute, Paiute, } \\
\text { Chumash (CH). }\end{array}$ & Stems, seeds & $\begin{array}{l}\text { Seeds, whole plant eaten } \\
(\mathbf{G} ; \mathbf{P})\end{array}$ & Unspecified & Unspecified & $\begin{array}{l}\text { Stems used in } \\
\text { arrowmaking (C; } \\
\text { CH), roof thatching } \\
\text { (C), brush handles, } \\
\text { knives, and tabacco } \\
\text { pipes. Used in house } \\
\text { construction, clothes, } \\
\text { and tools (CH). }\end{array}$ & $\begin{array}{l}\text { Bean and Saubel } \\
\text { 1972; Couplan 1998; } \\
\text { Ebeling 1986; } \\
\text { Kindscher 1987; } \\
\text { Moerman 1998; Smith } \\
\text { Jr. 2014; Timbrook } \\
\text { 1984. }\end{array}$ \\
\hline $\begin{array}{l}\text { L. triticoides } \\
\text { (Buckley) } \\
\text { Pilg. }\end{array}$ & $\begin{array}{l}\text { Paiute, Kawaiisu, } \\
\text { Potter Valley Pomo }\end{array}$ & Seeds & $\begin{array}{l}\text { Seeds pounded and } \\
\text { cooked to form a thick } \\
\text { mush (KW); pinole } \\
\text { (PVP). }\end{array}$ & Unspecified & Unspecified & Unspecified & $\begin{array}{l}\text { Ebeling 1986; } \\
\text { Couplan 1998; Smith } \\
\text { 1997; Smith Jr. 2014; } \\
\text { Welch 2013; Zigmond } \\
\text { 1981. }\end{array}$ \\
\hline
\end{tabular}

231 Table 2. Compilation of documented ethnobotanical records for 21 Elymus species.

232 "Unspecified" denotes where an indigenous community, plant part, or ethnobotanical use was 


\section{$\underline{\text { Results }}$}

Ethnobotanical analysis of Elymus

Of the ca. 150 known Elymus species, we identified 21 taxa that have documented ethnobotanical uses by people in North America and/or Eurasia (Table 2). Fifteen species are used as forage, 12 are used for food, six provide for raw materials for use in the home, and five are used medicinally. We identified at least 25 different indigenous communities that use Elymus

240 in some capacity. Five Native American communities use more than one species from the genus:

241 Gosiute (four species), Paiute (four), Kawaiisu (two), Potter Valley Pomo (two), and Iroquois

242 (two). Additionally, eight taxa in our study are used by more than one indigenous group ( $E$.

243 canadensis, E. elymoides Raf., E. glaucus, E. mollis, E. repens, L. cinereus, L. condensatus, and

244 L. triticoides. Forage uses are mainly as fodder, hay, and pasture grass. Food uses primarily

245 involve the seed, eaten raw (i.e. E. repens), as porridge or mash (i.e. E. glaucus, E. multisetus

246 J.G. Sm., E. repens), or as 'pinole,' a coarse flour made from ground seeds (i.e. E. elymoides).

247 Material uses are broad and encompassed many plant parts (culms, leaves, roots, and stems),

248 most frequently as components of houseware (i.e. basketry, broom handles). Medicinal uses are 249 equally diverse, with species being used in decoctions, infusions, and washes.

\section{Elymus species used for forage}

253 species are used for forage by at least one of seven indigenous communities across western

254 North America (Table 2). Forage uses are primarily for pasture grass, hay for livestock, and

255 fodder for antelope, buffalo deer, horses, and sheep. Seven species are used exclusively as forage

256 (there were no ethnobotanical records of use for food, medicine, or material for the species), 
257 whereas eight of the Elymus species used for forage are also human edible (Table 2). Many

258 Elymus species used as forage have specific environmental tolerances. For example, E. elongatus

259 Host. is used as a saline and alkaline tolerant pasture grass in western North America; $E$.

260 canadensis and E. smithii Rydb. are used for revegetation and reseeding of disturbed rangelands,

261 prairies, and saline soils of the Great Plains; and E. lanceolatus aids soil stabilization in the

262 intermountain region of the United States and Canada (Hanelt 2001). Two additional pasture

263 grass species (E. mutabilis Drobow and E. semicostatus) are cultivated for their frost and drought

264 resistance, respectively (Hanelt 2001). Finally, E. elymoides is edible to sheep and horses early in

265 the season and is used for this purpose by at least two southwestern Native American

266 communities, the Navajo and Ramah (Barkworth 2007; Moerman 1998).

\section{Elymus species used for human consumption}

Ten Elymus species are consumed by people in some form, and we identified six

270 indigenous communities that used Elymus for this purpose (Table 2). Elymus species eaten by

271 humans are: E. canadensis, E. elymoides, E. glaucus, E. mollis, E. multisetus, E. repens, E.

272 sibiricus L., L. cinerius, L. condensatus, and L. triticoides. For some species there is no

273 comprehensive description of preparation method (i.e. E. mollis). Several others illuminate

274 important details on food use; for example, seeds, roots, rhizomes, and leaves of E. repens are

275 consumed, either eaten raw, roasted, as a mash, or in a flour. Likewise, seeds of E. glaucus, E.

276 multisetus, and L. triticoides are parched, ground, and mixed with water to form a type of

277 porridge. Pinole is also a common preparation method for seed, and it is used as a flour in breads

278 (E. canadensis, E. elymoides, E. glaucus, L. triticoides), cereals, and casseroles (E. canadensis).

279 Notably, E. elymoides is considered "second in quality for [pinole]" following wild oats (Welch 
2013).

\section{Elymus species used for medicines and materials}

Elymus medicinal uses vary widely. Three taxa are used to treat renal and incontinence

River Indians imbricate stems of L. cinereus into baskets (Turner 1996), and E. arenarius L. is

295 formed into in ropes and brooms in parts of Eurasia (Hooker 1839). We found that roots, stems,

296 leaves, and culms of Elymus are all employed in material ways.

\section{Floret area measurements}

Floret area was measured for 21 Elymus species with documented use histories (see above). Floret area varies significantly across Elymus species $\left(F_{20}=13.37, P<0.0001\right)$, as well

301 as among individuals within species $\left(F_{21}=10.60, P<0.0001\right)$. Using species' means, we fit 
303 and within each of the four ethnobotanical categories (i.e. documented use vs. unspecified)

304 (Table 2). For medicine, floret area does not differ by region $\left(F_{1}=3.63, P>0.05\right.$; Figure 2$)$.

305 However, average floret area is significantly greater for species with medicinal uses compared to

306 species without documented medicinal uses in North America $\left(F_{1}=4.75, P=0.03\right.$; Figure $\left.2 \mathrm{a}\right)$.

307 In contrast, for food, forage, and material categories, floret area does not differ significantly by

308 region (Food: $F_{1}=4.01, P>0.05$; Forage: $F_{1}=3.93, P>0.05$; Material: $F_{1}=3.87, P>0.05$ ).

309 Additionally, no differences in floret area are observed when we compare average floret area for

310 species used for food, forage, and material to those without documented usage in each category,

311 (Food: $F_{1}=2.33, P>0.05$; Forage: $F_{1}=1.71, P>0.05$; Material; $F_{1}=1.24, P>0.05$ ). In

312 summary, average floret area does not differ significantly across geographic regions and among

313 documented ethnobotanical uses, with the exception of species used for medicine in North

314 America. Florets of species used medicinally were larger than florets of species not used

315 medicinally in this region. 

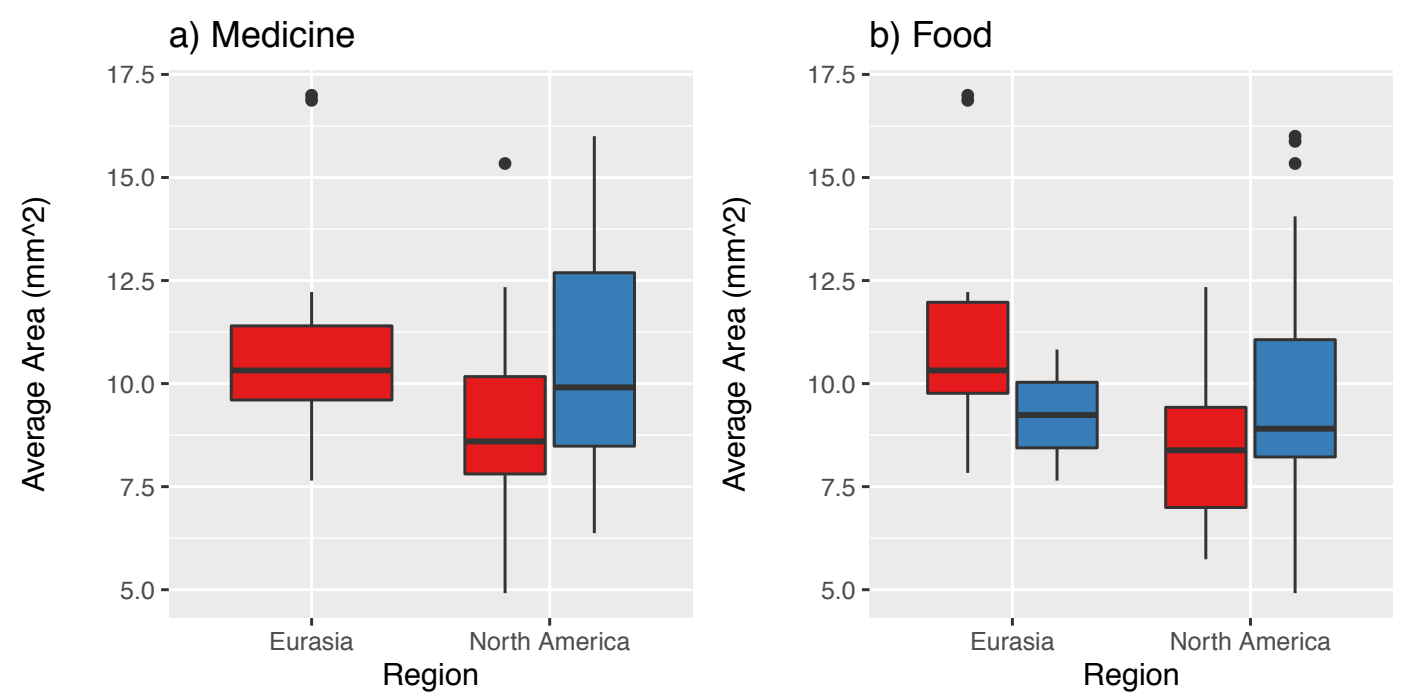

c) Forage
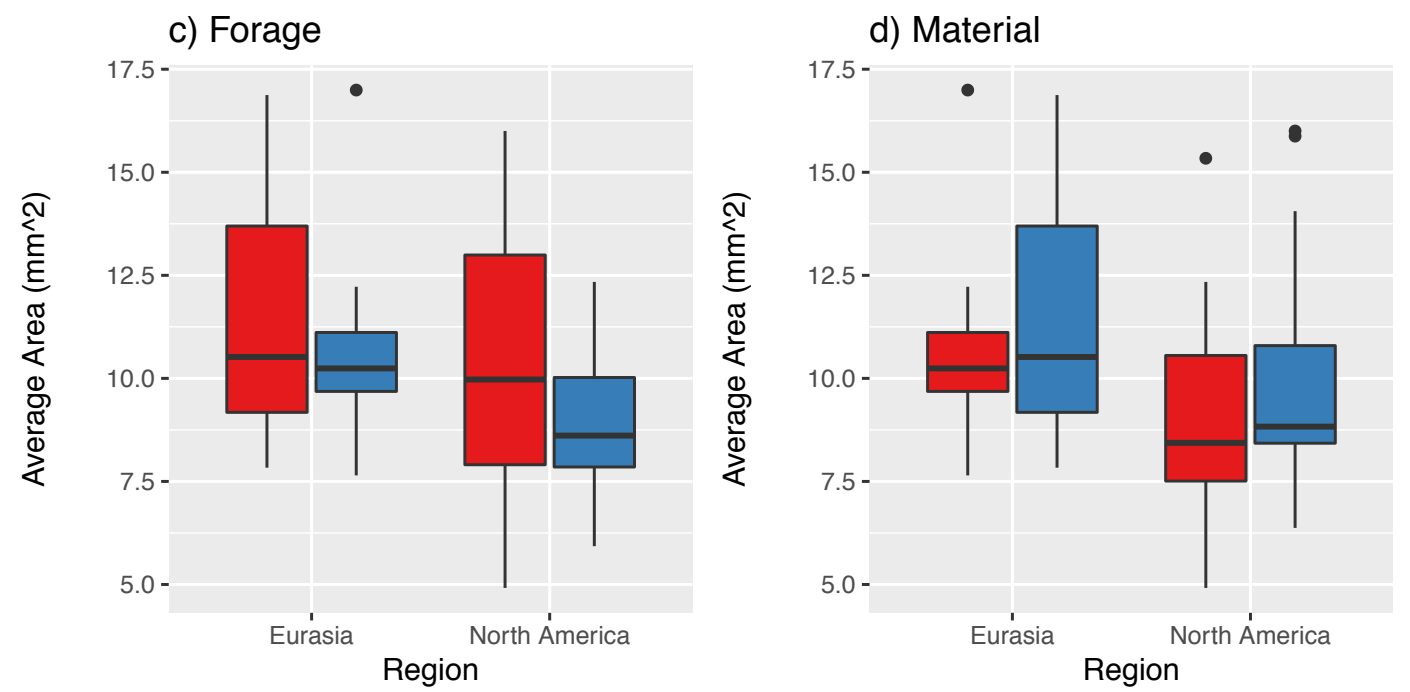

Figure 2. Comparison of average floret area by use (medicine, food, forage, and material) and region (North America, Eurasia). Blue denotes a documented use within that ethnobotanical category. Red denotes no documented use within that ethnobotanical category. Significant differences $\left(F_{1}=4.75, P=0.03\right)$ found only for medicinal uses in North America (2a).

To further investigate drivers of variation in average floret area across specimens, we tested for associations between average floret area, latitude, and longitude within region (i.e.

324 North America vs. Eurasia). In North America, average floret area increases from east to west ( $t$ 
$325=-2.41, P=0.02)$, but is not variable across latitudes $(t=1.52, P=0.14)$. In Eurasia, there is no

326 significant relationship between average floret area and latitude $(t=0.20, P=0.85)$ or longitude

$327(t=0.17, P=0.87)$; however, this may be an artifact of lower sampling in Eurasia in this study.

\section{$\underline{\text { Discussion }}$}

Growing concerns about ecological impacts of agricultural systems based on annual systems. Through their large, persistent root systems, among other traits, perennial, herbaceous plants offer ecological services including reduced erosion and increased absorption of water.

334 However, because of a dearth of herbaceous perennial crops, identifying potential candidates for

335 the ecological intensification of agriculture remains a challenge (Bommarco 2013).

336 Ethnobotanical records play an important role in this process by providing practical information

337 about wild plant use and morphology. Elymus is a genus of interest for pre-breeding and 338 domestication processes because of its rich ethnobotanical record, documented edibility, and 339 reproductive morphology. In addition, its history of hybridization suggests that members of the

340 genus may be intercrossed to develop new agricultural cultivars with beneficial trait

341 combinations. While there is no indication that native users of this group selected species with

342 larger floret areas for consumption, forage, or as material, significant variation in floret area

343 exists among and within species. Grain morphology is a valuable target of selection for

344 domestication in perennial grasses, and standing phenotypic variation in this group could serve

345 as a foundation for future breeding initiatives. Moreover, variation in use of Elymus species

346 illuminates the potential for broad application of this genus. 


\section{Ethnobotanical analyses as a foundation for agricultural innovation}

Ethnobotanical records are a vital source of information on plant diversity, use,

distribution, form, and function. In particular, ethnobotanical records can inform agricultural

processes by examining how plants have been manipulated or altered for human use (Casas et al.

1996). Further, these studies document which species were chosen for economic and cultural

purposes (Ford 2000). Additionally, ethnobotanical resources provide insight on geographic

distributions, environmental tolerances, toxicities, preparation methods, and human preferences

for certain features (flavors, shapes, textures, colors, etc.) of wild food plants (Casas et al. 1996).

These records thereby help identify species with agricultural potential, and provide pertinent

information on plant morphology and edibility in an agricultural context (Ciotir et al. 2019;

Minnis 2000; Plucknett and Smith 1986).

Our dataset identified 21 species of Elymus with known food, forage, medicine, and

material uses globally, and attributed these uses to at least 25 different indigenous communities.

The most frequent use of Elymus is as forage or fodder, further highlighting perennial members of Triticeae as globally important sources of forage grass (Kole 2011). We identified ten species of Elymus that are used for food (E.canadensis, E. elymoides, E. glaucus, E. mollis, E.

367 preparation methods for seed are straightforward (i.e. ground and mixed with water as a mash, or

368 finely pounded into flour), suggesting that their edibility is not contingent on rigorous 
371 species for their potential contribution to the ecological intensification of agriculture. Lastly, the

372 documentation of medicinal and material uses suggests that Elymus taxa are multifunctional, and

373 perhaps the whole plant can be employed post-production or at the end of their lifespan (i.e. as

374 hay for livestock or in thatching).

A previous ethnobotanical study of annual and perennial wild grass genera substantiated

376 their importance as a food source for Native American communities, including species from

377 Oryzopsis, Sporobolus, and Panicum and highlighted their potential to elucidate cereal

378 domestication processes (Doebley 1984). Similarly, ethnobotanical studies of other wild foods

379 have resulted in recommendations for their agricultural improvement, such as in grain chenopods

380 (Partap and Kapoor 1985). Other studies suggest improved collections of wild plants to

381 encourage their cultivation, such as in wild onion (Allium) (Bye 1985). Thus, in addition to

382 identifying potential crops, ethnobotanical studies can result in a variety of suggestions for pre-

383 breeding and domestication efforts in wild food plants.

Elymus is a cosmopolitan genus, and the 21 species in this study with documented

385 ethnobotanical uses have widely distributed native ranges, occurring across temperate North

386 America and Eurasia. While we identified documented uses for Elymus in several Eurasian

387 countries (Table 1), the depth of ethnobotanical information about Elymus species used in North

388 America was much greater. This disparity could be accredited to the fact that we primarily used

389 resources at the Missouri Botanical Garden library, thereby biasing the details of our study to

390 North America and to resources in English. As such, there are other globally-distributed Elymus

391 species that could have been used in an ethnobotanical capacity and that may also have potential

392 for use in pre-breeding and domestication programs. For example, wild relatives of sunflower

393 (Heliantheae) with larger ranges may have environmental tolerances and other traits useful to 
breeding initiatives (Kantar et al. 2015).

\section{Variation in floret traits of Elymus species}

Seed traits (floret traits in Elymus) are an important feature of wild and domesticated seed number exist for some species (Giles 1990; Jakobsson and Eriksson 2000). Similarly, during grain domestication, selection favors species and individuals with larger seeds, resulting in greater seedling vigor, root and shoot biomass, and yield, though the correlation of seed size to

404 plant size at maturity is weaker (Milla and Matesanz 2017; Preece et al. 2015; Rees and Venable 2007; Stougaard and Xue 2004). Further, it has been found that the progenitors of cereal crops have larger seeds than other wild grasses that have never undergone domestication (Preece et al. 2015). Given this information, we hypothesized that Elymus species with larger floret areas would perhaps be more frequently used as a food source and be more desirable for human consumption/domestication purposes. For the Elymus taxa examined in this study, we found significant differences in floret area between species and among replicates of a species. This

411 suggests that there is substantial natural variation in floret area within Elymus, an economically

412 and agriculturally important trait with potential for selection and evolution through the pre-

413 breeding process. From a conservation perspective, these data underscore the importance of a 414 dynamic in situ and ex situ conservation management that targets multiple species within a 415 genus, and diverse populations in different geographic locations (e.g., Khoury et al. 2019). 
417 American Elymus species. We cannot ensure that the specimens measured accurately reflect the

418 plants used by indigenous communities in the last three centuries. However, some studies

419 exploring seeds traits of medicinal plants assess seed size in relation to oil content (i.e. Moringa,

420 Mani et al. 2007; Pentaclethra, Asoegwu et al. 2006). The medicinal uses of vegetative plant

421 parts (i.e. roots) of Elymus exist, yet seeds were rarely described in a medicinal context (Table

422 2); therefore, the benefit of a larger floret area for medicinal applications should be further

423 investigated. For example, what properties of Elymus grains matter in medicinal applications

424 (oils, carbohydrates)? Are the grains ground, infused, or eaten directly in a medicinal context?

425 Future work could use voucher specimens from ethnobotanical studies to track the relationship

426 between medicinal use and floret area. Further, this study and others like it emphasize the

427 importance of plant use histories in conservation management, as different cultural communities

428 have unique and varied uses for the same species or closely related species; or, they have used

429 different species for similar purposes (e.g., Albuquerque et al. 2009)

430 Despite the wide variation in floret size within and among Elymus species, we did not

431 observe a significant relationship between average floret area, region, and documented

432 ethnobotanical use for the remaining three categories examined here (food, forage, and material).

433 It is conceivable that use of Elymus species for forage and material would not necessarily lead to

434 changes in seed size, as the primary structures being used (e.g., stems, leaves) may have been the

435 targets of selection. Data for these components of the plant were not collected in this study;

436 consequently, we are unable to assess whether or not forage and material uses led to changes in

437 these traits. Regarding food uses, archaeological analyses of taxa previously used for food have

438 demonstrated differences in seed size and other traits over time (Langlie et al. 2014; Mueller

439 2017), providing evidence for selection and domestication. The lack of association between 
440 floret size and use of Elymus for food in our dataset indicates that floret area was not associated

441 with utilization or consumption by indigenous communities. Detailed analyses of other traits,

442 including inflorescence size, plant height, historical abundance, may provide insights into

443 selection during at their time of use. Nonetheless, nearly all of the collections sampled in this

444 study were from the 20th century, and floret areas may have varied more significantly at the time

445 and place of use. Further, comparative analyses of the Elymus species with documented use

446 histories with other Elymus species for which no use history is known, might shed light on how

447 floret traits in Elymus species have changed through their interaction with humans. Floret and

448 grain traits remain important for de novo domestication in grasses and should be examined more

449 extensively in Elymus as well as other taxa of interest.

450

451

452

453

454

455

456

457

458

459

460

461

462

463

464

\section{Conclusions}

Morphological and genetic variation in cultivated plants, their wild progenitors, and other wild species provides the foundation for plant domestication and breeding efforts. In response to concerns about long-term sustainability of our current agricultural system, attention is focusing in part on de novo domestication of wild species (Ciotir et al. 2016; Ciotir et al. 2019; Kole 2011). As such, Elymus and many other genera of herbaceous perennials, merits increased attention to its research, development, and conservation. These efforts include improving the availability of Elymus germplasm in biorepositories globally in conjunction with expanding the collection of ethnobotanical histories throughout the genus. Additionally, we suggest more comprehensive morphological and molecular studies of taxa with documented food uses to more precisely identify promising candidates for agriculture. Similarly, we see value in in-situ conservation for genetically, phenotypically, and culturally valuable populations (i.e. at sites of indigenous use), as well as in-ground plantings to assess survivability in a controlled 
environment. Ultimately, a variety of Elymus species show promise for the ecological intensification of agriculture.

\section{Acknowledgements}

469 This research was supported by The Perennial Agriculture Project in conjunction with the

470 Malone Family Land Preservation Foundation and The Land Institute, the Missouri Botanical

471 Garden, and Saint Louis University. The authors are grateful to Dr. James Solomon and Dr.

472 Gerrit Davidse for their help in the Missouri Botanical Garden herbarium. We thank Dr. Laura

473 Klein and Zachary Harris for valuable comments on the manuscript.

\section{Author Contributions}

476 AJM, BM, CC, ESF, and MJR conceived of the study. BM, CC, and ESF collected the data. ESF

477 and MJR performed data analyses. AJM, BM, and ESF took the lead in writing the manuscript 478 and all authors contributed to manuscript editing.

\section{$\underline{\text { References }}$}

481 Albuquerque, U.P., Sousa Araújo, T.A., Ramos, M.A., Teixeira do Nascimento, V., Lucena,

482 R.F.P., Monteiro, J.M., Alencar, N.L., E. Lima Araújo. 2009. How Ethnobotany Can Aid

483 Biodiversity Conservation: Reflections on Investigations in the Semi-Arid Region of NE Brazil.

484 Biodiversity and Conservation 18(1): 127-50. https://doi.org/10.1007/s10531-008-9463-8.

486 Asoegwu, S., Ohanyere, S., Kanu, O.P., C.N. Iwueke. 2006. Physical Properties of African Oil

487 Bean Seed (Pentaclethra macrophylla). Agricultural Engineering International: the CIGR 
Ejournal. Manuscript FP 05006. Vol. VIII.

Aubry, C., Shoal, R., V. Erickson. 2005. Grass cultivars: their origins, development, and use on

491 national forests and grasslands in the Pacific Northwest. Pendleton (OR): USDA Forest Service,

492 Umatilla National Forest. Available at:

493 https://www.fs.fed.us/wildflowers/Native_Plant_Materials/documents/cultivars_maindoc_04040

$494 \quad 5$ appendices.pdf

496 Austin, D. F. 2004. Florida Ethnobotany. Boca Raton, FL: CRC.

Awika, J.M. 2011. Major Cereal Grains Production and Use around the World. Advances in

499 Cereal Science.

500

501 Barkworth, M.E. 2007. Triticeae. In: Flora of North America Magnoliophyta: Commelinidae (in

502 part): Poaceae, Part 1: North of Mexico. Vol 24, pp. 239-374. Oxford, Oxford University Press.

503

504 Bean, L. J., K.S. Saubel. 1972. Temalpakh: Cahuilla Indian knowledge and usage of plants.

505 Banning: Malki Museum.

506

507 Bommarco, R., Kleijn, D., S.G. Potts. 2013. Review: Ecological intensification: harnessing

508 ecosystem services for food security. Trends in Ecology \& Evolution, 28(4): 230-238.

509 https://doi: 10.1016/j.tree.2012.10.012.

510 Bye, R. A. 1985. Botanical perspectives of ethnobotany of the Greater Southwest. Economic 
Botany: 39(4), 375-386. doi:10.1007/bf02858744

512 Casas, A., del Carmen Vázquez, M., Viveros, J.L., J. Caballero. 1996. Plant Management

513 Among the Nahua and the Mixtec in the Balsas River Basin, Mexico: An Ethnobotanical

514 Approach to the Study of Plant Domestication. Human Ecology, 24(4): 455-478.

515 Cassman, K.G. 1999. Ecological intensification of cereal production systems: Yield potential,

516 soil quality, and precision agriculture. Proceedings National Academy of Sciences, 96(11): 5952-

517 5959. https://doi.org/10.1073/pnas.96.11.5952.

518 Chamberlin, L.V. 1911. The ethnobotany of the Gosiute Indians. Academy of Natural Sciences, 519 61(1): 24-99.

520

521 Chen, S., G., Zhu. 2006. Poaceae (Tribe Triticeae). Wu Z.Y. and Raven P.H. (eds.). Flora of

522 China, Vol. 22, Poaceae. 386-663. Science Press, Beijing, and Missouri Botanical Garden Press, 523 St. Louis.

524 Ciotir, C., Applequist, W., Crews, T.E., Cristea, N., DeHaan, L.R., Frawley, E., Herron, S., 525 Magill, R., Miller, J., Roskov, Y., Schlautman, B., Solomon, J., Townesmith, A., Van Tassel, D., 526 Zarucchi, J., A.J. Miller. 2019. Building a botanical foundation for perennial agriculture: Global 527 inventory of wild, perennial herbaceous Fabaceae species. Plants, People, Planet, 00: 1-12.

$528 \quad$ https://doi.org/10.1002/ppp3.37

529 Clayton, W.D., Vorontsova, M.S., Harman, K.T., H. Williamson. 2006 onwards. GrassBase 530 The Online World Grass Flora. http://www.kew.org/data/grasses-db.html 
532 Couplan, F. 1998. The Encyclopedia of Edible Plants of North America. Keats Publishing.

533

534 Cox, T.S., Bender, M., Picone, C., Van Tassel, D.L., Holland, J.B., Brummer, E.C., Zoeller,

535 B.E., Paterson, A.H., W. Jackson. 2002. Breeding perennial grain crops. Critical Reviews in

536 Plant Sciences, 21(2): 59-91.

537

538 Cox, T.S., Glover, J.D., Van Tassel, D.L., Cox, C.M., L.R. DeHaan. 2006. Prospects for

539 developing perennial grain crops. BioScience, 56(8): 649-659.

540

541 Cox, T.S. 2009. Chapter 1: Crop domestication and the first plant breeders. Pp 1-26 in S.

542 Ceccarelli; E.P. Guimar; E. Weltizien (eds.), Plant breeding and farmer participation. U.N. Food 543 and Agriculture Organization.

545 Cox, S., Nabukalu, P., Paterson, A. Kong, W., S. Nakasagga. 2018. Development of Perennial

546 Grain Sorghum. Sustainability, 10(1): 172-180. https://doi.org/10.3390/su10010172.

547 Doebley, J. F. 1984. "Seeds" of wild grasses: A major food of Southwestern Indians. Economic

548 Botany, 38(1): 52-64.doi:10.1007/bf02904415

549 Doré, T., Makowski, D., Malézieux, E., Munier-Jolain, N., Tchamitchian, M., P. Tittonell. 2011.

550 Facing up to the paradigm of ecological intensification in agronomy: Revisiting methods,

551 concepts and knowledge. European Journal of Agronomy, 34: 197-210.

552 https://doi:10.1016/j.eja.2011.02.006.

553 DeHaan, L.R., Christians, M., Crain, J. Poland. 2018. Development and Evolution of an 
554 Intermediate Wheatgrass Domestication Program. Sustainability, 10(5): 1499. https://doi.org/10.3390/su10051499

DeHaan, L. R., D. L. Van Tassel, J. A. Anderson, S. R. Asselin, R. Barnes, G. J. Baute, D. J.

557 Cattani, S. W. Culman, K. M. Dorn, B. S. Hulke, M. Kantar, S. Larson, M. D. Marks, A. J.

558 Miller, J. Poland, D. A. Ravetta, E. Rude, M. R. Ryan, D. Wyse, X. Zhang. 2016. A Pipeline

559 Strategy for Grain Crop Domestication. Crop Science, 56: 917-930.

560 doi:10.2135/cropsci2015.06.0356

561 DeHaan, L.R., D.L. Van Tassel. 2014. Useful insights from evolutionary biology for developing 562 perennial grain crops. American Journal of Botany, 101(10): 1801-1819.

563

564 DeHaan, L. R., Van Tassel D. L., T.S. Cox. 2010. Missing domesticated plant forms: can

565 artificial selection fill the gap? Evolutionary Applications, 3(5-6): 434-452.

566 doi: $10.1111 / \mathrm{j} .1752-4571.2010 .00132 . \mathrm{x}$

567 Ebeling, W. 1986. Handbook of Indian foods and fibers of arid America. Berkeley u.a.: Univ. of 568 Calif. Pr.

570 Elliot, B.A. 2009. Handbook of edible and poisonous plants of western North America. Elliot 571 Environmental Consulting, LLC.

573 Facciola. S. 1990. Cornucopia: A Source Book of Edible Plants. California: Kampong 574 Publications. 
577 derivatives. Hereditus, 98: 287-295.

578

579 Ferrier, J., Saciragic, L., Trakic, S., Chen, E.C.H., Gendron, R.L., Cuerrier, A., Balick, M.J.,

580 Redzic, S., Alikadic, E., J.T. Arnason. 2015. An ethnobotany of the Lukomir Highlanders of

581 Bosnia \& Herzegovina. Journal of Ethnobiology and Ethnomedicine, 11: 81.

583 Food and Agriculture Organization of the United Nations (FAO). 2009. A Global Treaty for

584 Food Security and Sustainable Agriculture, International Treaty on plant genetic resources for

585 food and agriculture. FAO, Rome: Electronic Publishing Policy and Support Branch

586 Communication Division.

588 Food and Agriculture Organization of the United Nations (FAO). 2019. The State of the World's

589 Biodiversity for Food and Agriculture, J. Bélanger \& D. Pilling (eds.). FAO Commission on

590 Genetic Resources for Food and Agriculture Assessments. Rome.

591 (http://www.fao.org/3/CA3129EN/CA3129EN.pdf)

592 Licence: CC BY-NC-SA 3.0 IGO.

593

594 Ford, R.I. 2000. Agriculture: An Introduction. in Minnis, P.E. (ed.) Ethnobotany: A Reader.

595 University of Oklahoma Press, Norman. Pp. 243.

596

597 Füleky, G. (ed.) 2009. Cultivated Plants, Primarily As Food Sources. Eolss Publishers Co. Ltd.

598 Oxford, United Kingdom. 
600 Gegas, V.C., Nazari, A., Griffiths, S., Simmonds, J., Fish, L., Orford, S., Sayers, L., Doonan,

601 J.H., J.W. Snape. 2010. A genetic framework for grain size and shape variation in wheat. Plant

602 Cell, 22(4): 1046-55. doi: 10.1105/tpc.110.074153.

603

604 Giles, B.E. 1990. The effects of variation in seed size on growth and reproduction in the wild

605 barley Hordeum vulgare ssp. Spontaneum. Heredity 64: 239-250.

606

607 Gregg, B.R., G.L. Billups. 2010. Seed Conditioning, Volume 3: Crop Seed Conditioning. CRC

608 Press. IBSN: 1439846715.

609

610 Glémin, S., T. Bataillon. 2009. A comparative view of the evolution of grasses under

611 domestication. New Phytologist, 183: 273-290.

612

613 Glover, J. D., J. P. Reganold, L. W. Bell, J. Borevitz, E. C. Brummer, E. S. Buckler, C. M. Cox,

614 et al. 2010. "Increased Food and Ecosystem Security via Perennial Grains." Science 328 (5986):

615 1638-39. https://doi.org/10.1126/science.1188761.

616

617 Hanelt, P. 2001. Mansfeld's Encyclopedia of Agricultural and Horticultural Crops, vol. 5. New

618 York, Berlin: Springer.

619

620 Harlan J., de Wet J., E. Price. 1973. Comparative evolution of cereals. Evolution, 27: 311-325.

621 DOI: 10.1111/j.1558-5646.1973.tb00676.x. 
623 Harlan, J.R. 1992. Crops and Man, 2nd Edition. American Society of Agronomy and Crop

624 Science Society of America, Madison, WI.

625

626 Hayes, R.C., Wang, S., Newell, M.T., Turner, K., Larsen, J., Gazza, L., Anderson, J.A., Bell,

627 L.W., Cattani, D.J., Frels, K., Galassi, E., Morgounov, A.I., Revell, C.K., Thapa, D.B., Sacks,

628 E.J., Sameri, M., Wade, L.J., Westerbergh, A., Shamanin, V., Amanov, A., G.D. Li. 2018. The

629 performance of early-generation perennial winter cereals at 21 sites across four continents.

630 Sustainability, 10(4):1124-1152. https://doi.org/10.3390/su10041124.

631

632 Helfgott, D.E, R.J. Mason-Gamer. 2004. The evolution of North America Elymus (Triticeae,

633 Poaceae) allotetraploids: evidence from phosphoenolpyruvate carboxylase gene sequences.

634 Systematic Botany, 29(4): 850-861.

635

636 Hooker, W.D. 1839. Notes on Norway; or a brief journal of a tour made to the Northern parts of

637 Norway, in the summer of MDCCCXXXVI.

638

639 Huang, G., Qin, S., Zhang, S., Cai, X.,Wu, S., Dao, J., Zhang, J., Huang, L., Harnpichitvitaya,

640 D., Wade, L., F. Hu. 2018. Performance, economics and potential impact of perennial rice PR23

641 relative to annual rice cultivars at multiple locations in Yunnan Province of China.

642 Sustainability, 10(4): 1086-1104. https://doi.org/10.3390/su10041086.

643

644 Jakobsson, A., O. Eriksson. 2000. A comparative study of seed number, seed size, seedling size

645 and recruitment in grassland plants. Oikos, 88(3): 494-502. doi:10.1034/j.1600- 
0706.2000.880304.x

647

648 Johnston, A. 1970. Blackfoot Indian utilization of the flora of the northwestern Great Plains.

649 Economic Botany, 24(3): 301-324.

650

651 Kantar, M. B., Sosa, C.C., Khoury, C.K., Castañeda-Álvarez, N.P., Achicanoy, H.A., Bernau, V.

652 Kane, N.C., Marek, L., Seiler, G., L. H. Rieseberg. 2015. Ecogeography and Utility to Plant

653 Breeding of the Crop Wild Relatives of Sunflower (Helianthus Annuus L.). Frontiers in Plant

654 Science 6: 841. https://doi.org/10.3389/fpls.2015.00841.

656 Kellogg, E.A. 2015. The Families and Genera of Vascular Plants: Flowering Plants, Monocots, 657 Poaceae. Switzerland, Springer International Publishing. et al. 2019. Comprehensiveness of Conservation of Useful Wild Plants: An Operational Indicator

661 for Biodiversity and Sustainable Development Targets. Ecological Indicators 98: 420-29. https://doi.org/10.1016/j.ecolind.2018.11.016

664 Khoury, C.K., Bjorkman, A.D., Dempewoldf, H., Ramirez-Villegas, J., Guarino, L., Jarvis, A., 665 Rieseberg, L.H., P.C. Struik. 2014. Increasing homogeneity in global food supplies.

666 Proceedings of the National Academy of Sciences, 111(11): 4001-4006. 
669 Kole, C. 2011. Wild crop relatives: genomic and breeding resources; cereals. Berlin Heidelberg,

670 Springer-Verlag.

671

672 Kunkel, G. 1984. Plants for human consumption: An Annotated Checklist of the Edible

673 Phanerogams and Ferns. Koeltz Scientific Books, Koenigstein.

674

675 Langlie, B.S., Mueller, N.G., Spengler, R.N., G.J. Fritz. 2014. Agricultural Origins From the

676 Ground Up: Archaeological Approaches to Plant Domestication. American Journal of Botany

677 101(10): 1601-1617.

678

679 Lantis, M. 1946. The social culture of the Nunivak Eskimo. Transactions of the American

680 Philosophical Society, 35(3): 153-323.

681

682 Lloyd-Reilley, J. 2010. Plant guide for Canada wildrye (Elymus canadensis). USDA-Natural

683 Resources Conservation Service, E. "Kika” de la Garza Plant Materials Center. Kingsville, TX.

684 Available at: https://plants.usda.gov/plantguide/pdf/pg_elca4.pdf [accessed June 21, 2019].

685

686 Lu, B.R. 1993. Biosystematic investigations of asiatic wheatgrasses-Elymus L. (Triticeae:

687 Poaceae). The Swedish University of Agricultural Sciences.

688

689 MacKinnon et al. 2009. Edible \& medicinal plants of Canada. Lone Pine Publishing.

690

691 Mani, S., Jaya, S., R. Vadivambal. 2007. Optimization of Solvent Extraction of Moringa 
(Moringa Oleifera) Seed Kernel Oil Using Response Surface Methodology. Food and

Bioproducts Processing 85(4): 328-335. https://doi.org/10.1205/fbp07075

694

Mueller, N.G. 2017. Veget Hist Archaeobot 26: 313. https://doi.org/10.1007/s00334-016-0592-9

696

697 Milla, R., S. Matesanz. 2017. Growing larger with domestication: a matter of physiology,

698 morphology or allocation? Plant Biology, 19(3), 475-483. doi:10.1111/plb.12545

699

700 Miller, A.J., Novy, A., Glover, J., Kellogg, E.A., Maul, J.E., Raven, P., P. Wyse Jackson. 2015.

701 Expanding the role of botanical gardens in the future of food. Nature Plants, 1(15078): doi:

$702 \quad 10.1038 /$ nplants.2015.78.

703

704 Millet, E. 1986. Relationships Between Grain Weight and the Size of Floret Cavity in the Wheat

705 Spike. Annals of Botany, 58(3): 417-423. http://www.jstor.org/stable/42757682

706

707 Millet, E., M.J. Pinthus. 1984. The association between grain volume and grain weight in wheat.

708 Cereal Science, 2(1): 31-35. https://doi.org/10.1016/S0733-5210(84)80005-3

709

710 Minnis, P.E. 2000. Ethnobotany: A Reader. University of Oklahoma Press, Norman.

711

712 Moerman, D. E. 1998. Native American ethnobotany. Timber Press, Portland.

713

714 National Geographic Society (NGS). 2008. Edible: an illustrated guide to the world's food 
plants. National Geographic Society, Washington D.C.

716

717 Okamoto, Y. Kajimura, T. Ikeda, T.M., S. Takumi. 2012. Evidence from principal component

718 analysis for improvement of grain shape and spikelet morphology related traits after hexaploid

719 wheat speciation. Genes Genet Syst, 87(5): 299-310.

720

721 Olsen, K.M., J.F. Wendel. 2013a. Crop plants as models for understanding plan adaptation and

722 diversification. Frontiers in Plant Science, 1(4): 290. doi: 10.3389/fpls.2013.00290.

723

724 Olsen, K.M., J.F. Wendel. 2013b. A bountiful harvest: genomic insights into crop domestication

725 phenotypes. Annual Reviews in Plant Biology, 64: 47-70. Doi: 10.1146/annurev-arplant-050312-

726120048.

727

728 Partap, T., P. Kapoor. 1985. The Himalayan Grain Chenopods: Distribution and Ethnobotany.

729 Agriculture, Ecosystems, and Environment, 14(3-4): 185-199. https://doi.org/10.1016/0167-

$730 \quad \underline{8809(85) 90035-0}$

731

732 Plucknett, D.L., N.J.H. Smith. 1986. International prospects for cooperation in crop research.

733 Economic Botany, 40(3): 298-309. doi:10.1007/bf02858987

734

735 Preece, C., Livarda, A., Wallace, M., Martin, G., Charles, M., Christin, P.A., Jones, G., Rees, M.,

736 C.P. Osborne. 2015. Were Fertile Crescent crop progenitors higher yielding than other wild

737 species that were never domesticated? New Phytologist, 207(3): 905-913. 
739 Rees M., D.L. Venable. 2007. Why do big plants make big seeds? Journal of Ecology 95: 926-

740936.

741

742 RStudio Team. 2015. RStudio: Integrated Development for R. RStudio, Inc., Boston, MA.

743 http://www.rstudio.com/.

744

745 Sargin, S.A., Akçicek, E., S. Selvi. 2013. An ethnobotanical study of the medicinal plants used

746 by the local people of Alasehir (Manisa) in Turkey. Journal of Ethnopharmacology, 150(3): 860-

747874.

748

749 SAS Institute, Base SAS 9.4 Procedures Guide: Statistical Procedures, Fifth Edition. SAS

750 Institute, 2017.

751

752 Schenck, S.M., E. W. Gifford. 1952. Karok Ethnobotany. Anthropological Records, 13(6): 377-

753392.

754

755 Smith, H. 1997. Ethnobotany of the Gitksan Indians of British Columbia. Canadian Museum of

756 Civilization.

757

758 Smith Jr., J. P. 2014. Field guide to grasses of California. University of California Press.

759

760 St. John, L., Jensen, K., Ogle, D.G., D. Tilley. 2010. Plant guide for RS Hybrid wheatgrass 
(Elymus hoffmannii). USDA-Natural Resources Conservation Service, Aberdeen, ID Plant

Materials Center and USDA-ARS Forage and Range Laboratory, Logan, UT. Available at:

763

https://plants.usda.gov/plantguide/pdf/pg_elho3.pdf

764

765 Stougaard, R.N., Q.W. Xue. 2004. Spring wheat seed size and seeding rate effects on yield loss

766 due to wild oat (Avena fatua) interference. Weed Science, 52: 133-141.

767

768

Tanaka, T. 1976. Tanaka's cyclopaedia of edible plants of the world. Keigaku Publishing.

769

770

Tilley, D., Ogle, D., L. St. John. 2011. Plant guide for slender wheatgrass (Elymus trachycaulus

771 ssp. trachycaulus). USDA-Natural Resources Conservation Service, Idaho Plant Materials

772 Center. Aberdeen, ID. https://plants.usda.gov/plantguide/pdf/pg_eltr7.pdf

773

774 Timbrook, J. 1984. Chumash Ethnobotany: A preliminary report. Journal of Ethnobiology, 4(2):

775 141-169.

776 Tittonell, P. 2014. Ecological intensification of agriculture — sustainable by nature. Current

777 Opinion in Environmental Sustainability, 8: 53-61. https://doi.org/10.1016/j.cosust.2014.08.006

778 Turner, N.J. 2010. Plants of Haida Gwaii. Winlaw, B.C.: Sono Nis Press.

779

780 Turner, N.J., Thomas, J., Carlson, B.F., R.T. Ogilvie. 1983. Ethnobotany of the Nitinaht Indians

781 of Vancouver Island. Victoria: Ministry of Provincial Secretary and Government Services,

782 Province of British Columbia. 
784 Turner, N.J., Thompson, L.C., Thompson, M.T., A.Z. York. 1996. Thompson ethnobotany:

785 knowledge and usage of plants by the Thompson Indians of British Columbia. Victoria, B.C:

786 Royal British Columbia Museum.

787

788 Wang, S.L., Qi, L.L., Chen, P.D., Liu, D.J., Friebe, B., B.S. Gill. 1999. Molecular cytogenetic

789 identification of wheat-Elymus tsukushiense introgression lines. Euphytica, 107: 217-224.

790

791 Warren, J. 2015. The nature of crops: how we came to eat the plants we do. Wallingford: CABI.

$792 \quad 1780645082$.

793

794 Waugh, F.W. 1916. Iroquois Foods and Food Preparation. University Press of the Pacific. ISBN 7951410207765.

796

797 Welch, J.R. 2013. Sprouting valley historical ethnobotany of the northern pomo from Potter

798 Valley, California. Denton, TX: Society of Ethnobiology.

799

800 Yanovsky, E. 1936. Food plants of the North American Indians. Publication no. 237. U.S. Dept

801 of Agriculture.

802

803 Zigmond, M.L.1981. Kawaiisu Ethnobotany. Salt Lake City: Univ. of Utah Press.

804

805 Zohary, D., Hopf, M. E. Weiss (eds.). 2012. Domestication of Plants in the Old World. 4th

806 edition. New York: Oxford University Press. 


\section{Table Captions}

812 Table 1 caption: Native ranges and location of ethnobotanical use for 21 Elymus species.

813 Table 2 caption: Compilation of documented ethnobotanical records for 21 Elymus species.

814 "Unspecified" denotes where an indigenous community, plant part, or ethnobotanical use was

815 not documented for a given species in the literature we consulted.

\section{$817 \quad$ Figure Captions}

818 Figure 1 caption: Geographic locations of collection sites for all specimens measured across 21

819 Elymus species. Collection site determined from herbarium specimen label.

820 Figure 2 caption: Comparison of average floret area by use (medicine, food, forage, and 821 material) and region (North America, Eurasia). Blue denotes a documented use within that

822 ethnobotanical category. Red denotes no documented use within that ethnobotanical category.

823 Significant differences $\left(F_{1}=4.75, P=0.03\right)$ found only for medicinal uses in North America $824(2 \mathrm{a})$.

\section{Appendix Captions}

827 Appendix 1 caption: Herbarium specimen information from which florets were harvested for area measurements. $*=$ Specific latitudes and longitudes were not available at time of collection, 
bioRxiv preprint doi: https://doi.org/10.1101/734525; this version posted August 15,2019 . The copyright holder for this preprint (which was not certified by peer review) is the author/funder, who has granted bioRxiv a license to display the preprint in perpetuity. It is made available under aCC-BY-ND 4.0 International license.

829 so coordinates were estimated in Google Earth for general analyses in R based off of detailed

830 geographic information provided on the specimen.

831 Appendix 2 caption: Individual floret area measurements for 21 Elymus species and replicates. 
bioRxiv preprint doi: https://doi org/10,1101/734525; this version posted August 15,2019 . The copyright holder for this preprint (which was not certified by peer review) is the author/funder, who has granted bioRxiv a license to display the preprint in perpetuity. It is made available under aCC-BY-ND 4.0 International license.

\section{Herbarium Specimen Collection Locations}

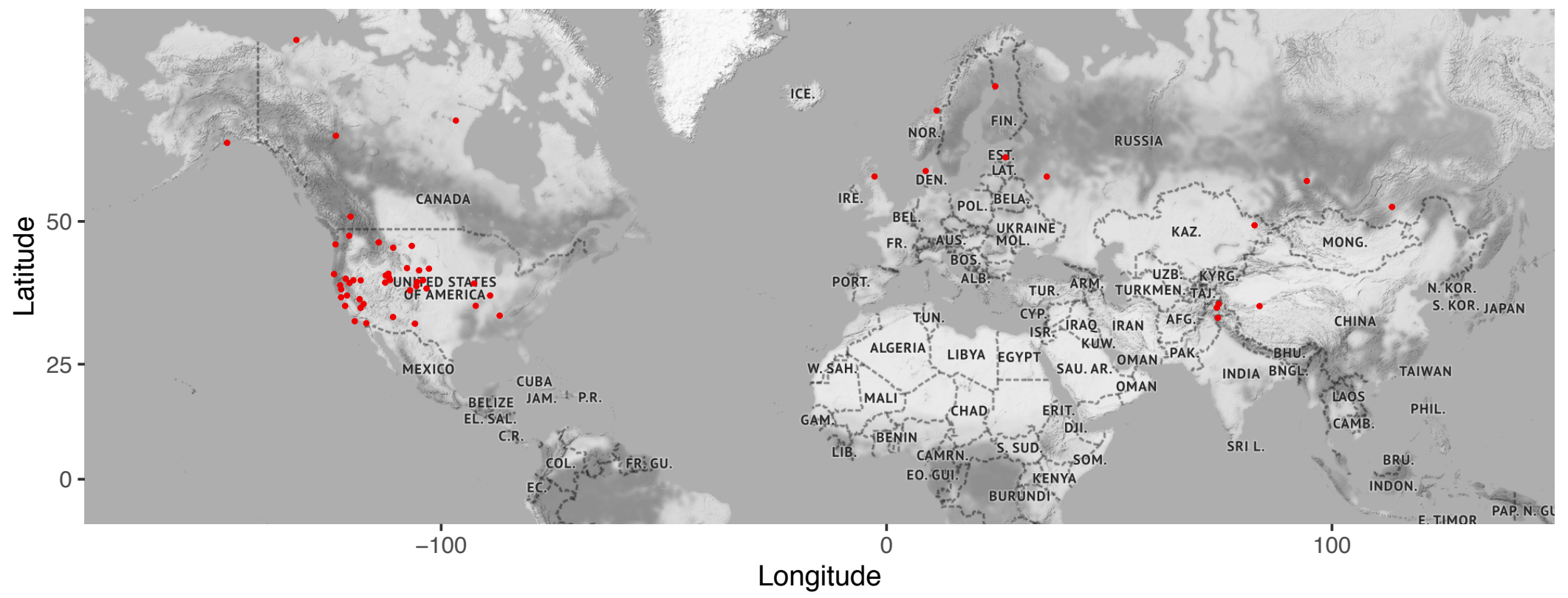




\begin{tabular}{|c|c|c|}
\hline Species & Use Distribution & Native Range \\
\hline$\overline{E .} \operatorname{arenarius}(\mathrm{L})$. & Eurasia (NOR) & Eurasia \\
\hline E. canadensis (L.) & North America (UT, CO) & North America \\
\hline E. caninus $(\mathrm{L})$. & Eurasia (RUS, CHN) & Temperate Asia \\
\hline E. elongatus (Host.) & North America (USA, CAN) & Eurasia \\
\hline E. elymoides (Raf.) & North America (CA) & $\begin{array}{l}\text { North America, } \\
\text { Temperate Asia }\end{array}$ \\
\hline E. fibrosus (Schrenk) & Eurasia (RUS) & Temperate Asia \\
\hline E. glaucus (Buckley) & North America (CA, NM, BC) & $\begin{array}{l}\text { North America, } \\
\text { Temperate Asia }\end{array}$ \\
\hline E. hystrix (Moench) & North America (FL) & North America \\
\hline $\begin{array}{l}\text { E. lanceolatus (Scribn. \& } \\
\text { J.G. Sm.) }\end{array}$ & North America (USA, CAN) & $\begin{array}{l}\text { North America, } \\
\text { Temperate Asia }\end{array}$ \\
\hline E. mollis (Trin.) & North America (AK, BC, WA) & $\begin{array}{l}\text { North America, } \\
\text { Eurasia }\end{array}$ \\
\hline E. multisetus (J.G. Sm.) & North America (CA) & North America \\
\hline E. mutabilis (Drobow) & Eurasia (RUS) & Eurasia \\
\hline E. repens (L.) & $\begin{array}{l}\text { North America (USA, CAN); Eurasia (FIN, } \\
\text { SWE, RUS, TUR, BIH, IRL) }\end{array}$ & Eurasia \\
\hline $\begin{array}{l}\text { E. semicostatus (Nees ex } \\
\text { Steud.) }\end{array}$ & North America (USA); Eurasia (JPN) & Asia \\
\hline E. sibiricus (L.) & North America (UT); Eurasia (RUS) & $\begin{array}{l}\text { North America, } \\
\text { Eurasia }\end{array}$ \\
\hline E. smithii (Rydb.) & North America (USA, CAN) & North America \\
\hline E. spicatus (Pursh) & North America (USA) & North America \\
\hline E. trachycaulus (Link) & North America (USA, CAN); Eurasia (RUS) & $\begin{array}{l}\text { North America, } \\
\text { Eurasia }\end{array}$ \\
\hline $\begin{array}{l}\text { L. cinereus (Scribn. \& } \\
\text { Merr.) }\end{array}$ & North America (AB, BC, MT, UT, CA) & North America \\
\hline L. condensatus (J. Presl) & North America (UT, CA) & North America \\
\hline L. triticoides (Buckley) & North America (CA) & North America \\
\hline
\end{tabular}




\begin{tabular}{|c|c|c|c|c|c|c|c|}
\hline Species & $\begin{array}{l}\text { Indigenous } \\
\text { Communities }\end{array}$ & $\begin{array}{l}\text { Plant Part } \\
\text { Used }\end{array}$ & Food Uses & $\begin{array}{l}\text { Medicinal } \\
\text { Uses }\end{array}$ & Forage Uses & Material Uses & References \\
\hline $\begin{array}{l}\text { E. arenarius } \\
\text { (L.) }\end{array}$ & Unspecified & Unspecified & Unspecified & Unspecified & Unspecified & $\begin{array}{l}\text { Twisting ropes } \\
\text { and making } \\
\text { brooms. }\end{array}$ & $\begin{array}{l}\text { Hooker 1839; } \\
\text { Moerman1998. }\end{array}$ \\
\hline $\begin{array}{l}\text { E. canadensis } \\
\text { (L.) }\end{array}$ & $\begin{array}{l}\text { Gosiute }(\mathbf{G}), \\
\text { Iroquois }(\mathbf{I}), \\
\text { Kiowa }(\mathbf{K}), \text { Ute } \\
(\mathbf{U}), \text { Paiute }(\mathbf{P})\end{array}$ & $\begin{array}{l}\text { Seeds, roots, } \\
\text { and foliage }\end{array}$ & $\begin{array}{l}\text { Gathered }(\mathbf{G}, \\
\mathbf{U}) \text {, ground } \\
\text { into flour, } \\
\text { used to make } \\
\text { bread, cereals, } \\
\text { rye casserole. }\end{array}$ & $\begin{array}{l}\text { Compound } \\
\text { decoction of } \\
\text { roots taken } \\
\text { for the } \\
\text { kidneys }(\mathbf{I}) \text {. }\end{array}$ & $\begin{array}{l}\text { Fodder }(\mathbf{K}) ; \\
\text { forage for } \\
\text { deer, } \\
\text { antelope, and } \\
\text { buffalo }(\mathbf{P}) ; \\
\text { cultivated as } \\
\text { a pasture } \\
\text { grass }(\mathbf{P}) .\end{array}$ & Unspecified & $\begin{array}{l}\text { Facciola 1990; } \\
\text { Kindscher } 1987 ; \\
\text { Kunkel 1984; } \\
\text { Moerman 1998; } \\
\text { Tanaka 1976; } \\
\text { Yanovsky } 1936 .\end{array}$ \\
\hline $\begin{array}{l}\text { E. caninus } \\
\text { (L.) }\end{array}$ & Unspecified & Unspecified & Unspecified & Unspecified & Forage grass. & Unspecified & Hanelt 2001. \\
\hline $\begin{array}{l}\text { E. elongatus } \\
\text { (Host.) }\end{array}$ & Unspecified & Unspecified & Unspecified & Unspecified & $\begin{array}{l}\text { Hay and } \\
\text { pasture crop. }\end{array}$ & Unspecified & Hanelt 2001. \\
\hline $\begin{array}{l}\text { E. elymoides } \\
\text { (Raf.) }\end{array}$ & $\begin{array}{l}\text { Navajo (N), } \\
\text { Ramah (R), } \\
\text { Potter Valley } \\
\text { Pomo (PVP) }\end{array}$ & Seeds & $\begin{array}{l}\text { As pinole, } \\
\text { considered } \\
\text { second best } \\
\text { quality after } \\
\text { wild oats } \\
\text { (PVP). }\end{array}$ & Unspecified & $\begin{array}{l}\text { Young } \\
\text { plants used } \\
\text { for sheep } \\
\text { and horse } \\
\text { feed }(\mathbf{N}, \mathbf{R}) \text {. }\end{array}$ & Unspecified & $\begin{array}{l}\text { Moerman 1998; } \\
\text { Welch } 2013 .\end{array}$ \\
\hline $\begin{array}{l}\text { E. fibrosus } \\
\text { (Schrenk) }\end{array}$ & Unspecified & Unspecified & Unspecified & Unspecified & $\begin{array}{l}\text { Minor forage } \\
\text { crop. }\end{array}$ & Unspecified & $\begin{array}{l}\text { Clayton et al. } \\
\text { 2006; Hanelt } \\
2001 .\end{array}$ \\
\hline $\begin{array}{l}\text { E. glaucus } \\
\text { (Buckley) }\end{array}$ & $\begin{array}{l}\text { Karok }(\mathbf{K A}), \\
\text { Keres }(\mathbf{K E}), \\
\text { Gitksan }(\mathbf{G I})\end{array}$ & Seeds & $\begin{array}{l}\text { As porridge } \\
\text { (seeds } \\
\text { parched, } \\
\text { pounded into } \\
\text { a flour, and } \\
\text { mixed with } \\
\text { water into a } \\
\end{array}$ & $\begin{array}{l}\text { To settle } \\
\text { quarrels } \\
\text { between } \\
\text { families or } \\
\text { individuals } \\
\text { (KA). }\end{array}$ & $\begin{array}{l}\text { Forage for } \\
\text { deer, } \\
\text { antelope, and } \\
\text { buffalo; } \\
\text { potential } \\
\text { pasture and } \\
\text { forage crop. }\end{array}$ & $\begin{array}{l}\text { Used in socks } \\
\text { and stuffing } \\
\text { inside } \\
\text { moccasins, as } \\
\text { baby bedding, } \\
\text { and to cover } \\
\text { ground where }\end{array}$ & $\begin{array}{l}\text { Couplan 1998; } \\
\text { Ebeling 1986; } \\
\text { Hanelt 2001; } \\
\text { Moerman 1998; } \\
\text { Schenck 1952; } \\
\text { Smith 1997; } \\
\text { Smith Jr. 2014; }\end{array}$ \\
\hline
\end{tabular}




\begin{tabular}{|c|c|c|c|c|c|c|c|}
\hline & & & $\begin{array}{l}\text { paste), } \\
\text { cooked, or } \\
\text { ground into } \\
\text { bread flour } \\
\text { (KA). }\end{array}$ & & & $\begin{array}{l}\text { people sat } \\
\text { around fire } \\
(\mathbf{G I}) .\end{array}$ & $\begin{array}{l}\text { Tanaka 1976; } \\
\text { Yanovsky } 1936 .\end{array}$ \\
\hline $\begin{array}{l}\text { E. hystrix } \\
\text { (Moench) }\end{array}$ & Iroquois & Unspecified & Unspecified & $\begin{array}{l}\text { Ceremonial: } \\
\text { decoction } \\
\text { for corn } \\
\text { seeds }(\mathbf{I}) \text {. }\end{array}$ & Unspecified & Unspecified & Austin 2004. \\
\hline $\begin{array}{l}\text { E. } \\
\text { lanceolatus } \\
\text { (Scribn. \& } \\
\text { J.G. Sm.) }\end{array}$ & Unspecified & Unspecified & Unspecified & Unspecified & $\begin{array}{l}\text { Cultivated as } \\
\text { forage grass } \\
\text { and pasture } \\
\text { crop. }\end{array}$ & Unspecified & Hanelt 2001. \\
\hline $\begin{array}{l}\text { E. mollis } \\
\text { (Trin.) }\end{array}$ & $\begin{array}{l}\text { Nitinaht (NI), } \\
\text { Makah }(\mathbf{M}), \\
\text { Haida }(\mathbf{H}), \\
\text { Nunivak } \\
\text { Eskimo (NE) }\end{array}$ & $\begin{array}{l}\text { Seeds, stems, } \\
\text { leaves, and } \\
\text { roots }\end{array}$ & Seeds eaten. & $\begin{array}{l}\text { Roots } \\
\text { twisted } \\
\text { together to } \\
\text { form rope, } \\
\text { rubbed on } \\
\text { the bodies } \\
\text { of young } \\
\text { men for } \\
\text { strength } \\
\text { (NI); basal } \\
\text { portion of } \\
\text { stem } \\
\text { chewed for } \\
\text { incontinenc } \\
\text { e }(\mathbf{M}) \text {. }\end{array}$ & Unspecified & $\begin{array}{l}\text { Tough leaves } \\
\text { used for sewing } \\
\text { (NI), plants } \\
\text { gathered, split, } \\
\text { dyed, and used } \\
\text { in basketry and } \\
\text { mats (H; NE). }\end{array}$ & $\begin{array}{l}\text { Couplan 1998; } \\
\text { Turner et al. } \\
\text { 1983; Turner } \\
\text { 2010; Lantis } \\
1946 .\end{array}$ \\
\hline $\begin{array}{l}\text { E. multisetus } \\
\text { (J.G. Sm.) }\end{array}$ & Kawaiisu (KW) & Seeds & $\begin{array}{l}\text { Pounded into } \\
\text { a } \\
\text { porridge/mush } \\
(\mathbf{K W}) \text {. }\end{array}$ & Unspecified & Unspecified & Unspecified & $\begin{array}{l}\text { Moerman 1998; } \\
\text { Smith Jr. } 2014 .\end{array}$ \\
\hline E. mutabilis & Unspecified & Unspecified & Unspecified & Unspecified & Frost- & Unspecified & Hanelt 2001. \\
\hline
\end{tabular}




\begin{tabular}{|c|c|c|c|c|c|c|c|}
\hline (Drobow) & & & & & $\begin{array}{l}\text { resistent } \\
\text { forage grass. }\end{array}$ & & \\
\hline E. repens (L.) & $\begin{array}{l}\text { Apache }(\mathbf{A}), \\
\text { White Mountain } \\
(\mathbf{W M}), \\
\text { Cherokee } \\
(\mathbf{C H E}), \\
\text { Gosiute, } \\
\text { Iroquois, } \\
\text { Okanagan- } \\
\text { Colville (OC), } \\
\text { Lukomir } \\
\text { Highlanders } \\
\text { (LH) }\end{array}$ & $\begin{array}{l}\text { Seeds, stems, } \\
\text { rhizomes, } \\
\text { roots, shoots, } \\
\text { and leaves }\end{array}$ & $\begin{array}{l}\text { Roots dried, } \\
\text { ground into } \\
\text { meal, and } \\
\text { substituted for } \\
\text { bread; } \\
\text { rhizomes } \\
\text { dried and } \\
\text { ground, } \\
\text { roasted for } \\
\text { coffee, or } \\
\text { boiled into a } \\
\text { syrup for beer; } \\
\text { seeds, tips of } \\
\text { rhizomes, } \\
\text { leaves and } \\
\text { shoots eaten } \\
\text { raw; seed } \\
\text { mashed (A; } \\
\text { WM; G). }\end{array}$ & $\begin{array}{l}\text { Orthopedic } \\
\text { and } \\
\text { unrinary aid } \\
\text { (CHE; I); } \\
\text { decoction } \\
\text { used to } \\
\text { wash } \\
\text { swollen legs } \\
\text { and infusion } \\
\text { taken for } \\
\text { gravel, } \\
\text { incontinenc } \\
\text { e, and } \\
\text { bedwetting } \\
\text { (CHE); } \\
\text { roots } \\
\text { infused to } \\
\text { make } \\
\text { kidney and } \\
\text { genitourinar } \\
\text { y treatment; } \\
\text { rhizomes to } \\
\text { treat kidney, } \\
\text { liver, and } \\
\text { urinary } \\
\text { problems; } \\
\text { worm } \\
\text { expellant } \\
\text { (I); to treat } \\
\text { poor } \\
\text { eyesight, }\end{array}$ & 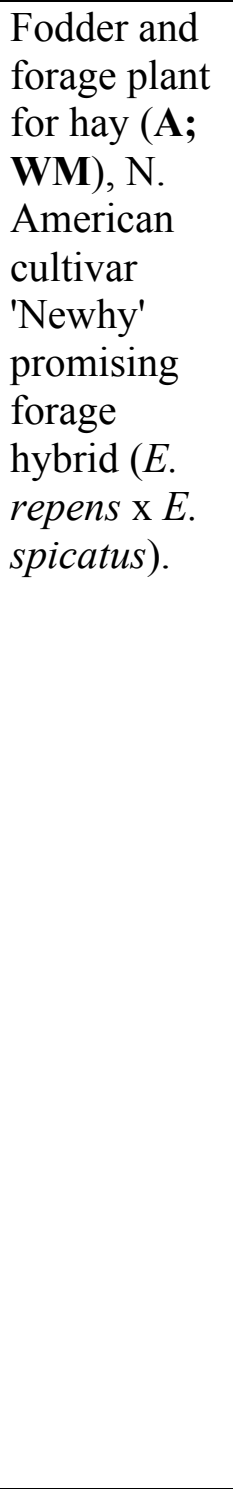 & $\begin{array}{l}\text { Used under and } \\
\text { over food in pit } \\
\text { cooking (OC). }\end{array}$ & $\begin{array}{l}\text { Allen and } \\
\text { Hatfield 2004; } \\
\text { Elliot 2009; } \\
\text { Ferrier et al. } \\
\text { 2015; Hanelt } \\
\text { 2001; Jackson } \\
\text { 2014; } \\
\text { MacKinnon et } \\
\text { al. 2009; } \\
\text { Moerman 1998; } \\
\text { Sargin 2013. }\end{array}$ \\
\hline
\end{tabular}




\begin{tabular}{|c|c|c|c|c|c|c|c|}
\hline & & & & $\begin{array}{l}\text { chest pain, } \\
\text { fever, } \\
\text { syphilis, } \\
\text { jaundice, } \\
\text { and swollen } \\
\text { and } \\
\text { rheumatic } \\
\text { limbs; other } \\
\text { medicinal } \\
\text { uses }(\mathbf{L H}) \text {. }\end{array}$ & & & \\
\hline $\begin{array}{l}\text { E. } \\
\text { semicostatus } \\
\text { (Nees ex } \\
\text { Steud.) }\end{array}$ & Unspecified & Unspecified & Unspecified & Unspecified & $\begin{array}{l}\text { Drought- } \\
\text { resistent } \\
\text { pasture } \\
\text { grass. }\end{array}$ & Unspecified & $\begin{array}{l}\text { Clayton et al. } \\
\text { 2006; Hanelt } \\
2001 \text {. }\end{array}$ \\
\hline $\begin{array}{l}\text { E. sibiricus } \\
\text { (L.) }\end{array}$ & Gosiute & Seeds & Yes $(\mathbf{G})$. & Unspecified & $\begin{array}{l}\text { Infrequently } \\
\text { cultivated as } \\
\text { forage grass. }\end{array}$ & Unspecified & $\begin{array}{l}\text { Chamberlin } \\
\text { 1911; Clayton et } \\
\text { al. 2006; Hanelt } \\
\text { 2001; Moerman } \\
\text { 1998. }\end{array}$ \\
\hline $\begin{array}{l}\text { E. smithii } \\
\text { (Rydb.) }\end{array}$ & Unspecified & Unspecified & Unspecified & Unspecified & $\begin{array}{l}\text { Cultivated } \\
\text { for hay and } \\
\text { pasture. }\end{array}$ & Unspecified & $\begin{array}{l}\text { Clayton et al. } \\
\text { 2006; Hanelt } \\
\text { 2001. }\end{array}$ \\
\hline $\begin{array}{l}\text { E. spicatus } \\
\text { (Pursh) }\end{array}$ & Unspecified & Unspecified & Unspecified & Unspecified & $\begin{array}{l}\text { Forage grass } \\
\text { for natural } \\
\text { pastures. }\end{array}$ & Unspecified & $\begin{array}{l}\text { Clayton et al. } \\
\text { 2006; Hanelt } \\
2001 \text {. }\end{array}$ \\
\hline $\begin{array}{l}\text { E. } \\
\text { trachycaulus } \\
\text { (Link) }\end{array}$ & Unspecified & Seeds & Unspecified & Unspecified & $\begin{array}{l}\text { Cultivated } \\
\text { mostly in } \\
\text { grass } \\
\text { mixtures as } \\
\text { forage and } \\
\text { pasture } \\
\text { plant. }\end{array}$ & Unspecified & $\begin{array}{l}\text { Clayton et al. } \\
\text { 2006; Hanelt } \\
\text { 2001; Smith Jr. } \\
2014 \text {. }\end{array}$ \\
\hline L. cinereus & Paiute, & Seeds, stems, & Seeds eaten & Unspecified & Hay for & Stems used for & Ebeling 1986; \\
\hline
\end{tabular}




\begin{tabular}{|c|c|c|c|c|c|c|c|}
\hline $\begin{array}{l}\text { (Scribn. \& } \\
\text { Merr.) Á. } \\
\text { Löve }\end{array}$ & $\begin{array}{l}\text { Thompson (T), } \\
\text { Blackfoot (B) }\end{array}$ & $\begin{array}{l}\text { leaves, and } \\
\text { culm }\end{array}$ & $(\mathbf{P})$. & & $\begin{array}{l}\text { livestock } \\
\text { (T). }\end{array}$ & $\begin{array}{l}\text { basket } \\
\text { imbrication; } \\
\text { leaves used to } \\
\text { line graves; } \\
\text { culms used as } \\
\text { "fish spreaders" } \\
\text { or for cleaning; } \\
\text { grass used as } \\
\text { bedding }(\mathbf{T}) \text {. }\end{array}$ & $\begin{array}{l}\text { Johnston 1970; } \\
\text { Turner et al. } \\
\text { 1996; Smith Jr. } \\
2014 \text {. }\end{array}$ \\
\hline $\begin{array}{l}L . \\
\text { condensatus } \\
\text { (J. Presl) Á. } \\
\text { Löve }\end{array}$ & $\begin{array}{l}\text { Cahuilla }(\mathbf{C}), \\
\text { Gosiute, Paiute, } \\
\text { Chumash }(\mathbf{C H}) .\end{array}$ & Stems, seeds & $\begin{array}{l}\text { Seeds, whole } \\
\text { plant eaten } \\
\text { (G; P) }\end{array}$ & Unspecified & Unspecified & $\begin{array}{l}\text { Stems used in } \\
\text { arrowmaking } \\
(\mathbf{C} ; \mathbf{C H}), \text { roof } \\
\text { thatching }(\mathbf{C}) \text {, } \\
\text { brush handles, } \\
\text { knives, and } \\
\text { tabacco pipes. } \\
\text { Used in house } \\
\text { construction, } \\
\text { clothes, and } \\
\text { tools }(\mathbf{C H}) .\end{array}$ & $\begin{array}{l}\text { Bean and } \\
\text { Saubel 1972; } \\
\text { Couplan 1998; } \\
\text { Ebeling 1986; } \\
\text { Kindscher 1987; } \\
\text { Moerman 1998; } \\
\text { Smith Jr. 2014; } \\
\text { Timbrook 1984. }\end{array}$ \\
\hline $\begin{array}{l}\text { L. triticoides } \\
\text { (Buckley) } \\
\text { Pilg. }\end{array}$ & $\begin{array}{l}\text { Paiute, } \\
\text { Kawaiisu, } \\
\text { Potter Valley } \\
\text { Pomo }\end{array}$ & Seeds & $\begin{array}{l}\text { Seeds } \\
\text { pounded and } \\
\text { cooked to } \\
\text { form a thick } \\
\text { mush (KW); } \\
\text { pinole (PVP). }\end{array}$ & Unspecified & Unspecified & Unspecified & $\begin{array}{l}\text { Ebeling 1986; } \\
\text { Couplan 1998; } \\
\text { Smith 1997; } \\
\text { Smith Jr. 2014; } \\
\text { Welch 2013; } \\
\text { Zigmond 1981. }\end{array}$ \\
\hline
\end{tabular}


